\title{
Fuel Sensitivity and Parametric Optimization of SOFC - GT Hybrid System Operational Characteristics
}

DOI:

10.1016/j.tsep.2019.100407

\section{Document Version}

Accepted author manuscript

Link to publication record in Manchester Research Explorer

\section{Citation for published version (APA):}

Huang, Y., \& Turan, A. (2019). Fuel Sensitivity and Parametric Optimization of SOFC - GT Hybrid System Operational Characteristics. Thermal Science and Engineering Progress.

https://doi.org/10.1016/j.tsep.2019.100407

\section{Published in:}

Thermal Science and Engineering Progress

\section{Citing this paper}

Please note that where the full-text provided on Manchester Research Explorer is the Author Accepted Manuscript or Proof version this may differ from the final Published version. If citing, it is advised that you check and use the publisher's definitive version.

\section{General rights}

Copyright and moral rights for the publications made accessible in the Research Explorer are retained by the authors and/or other copyright owners and it is a condition of accessing publications that users recognise and abide by the legal requirements associated with these rights.

\section{Takedown policy}

If you believe that this document breaches copyright please refer to the University of Manchester's Takedown Procedures [http://man.ac.uk/04Y6Bo] or contact uml.scholarlycommunications@manchester.ac.uk providing relevant details, so we can investigate your claim.

\section{OPEN ACCESS}




\title{
Fuel Sensitivity and Parametric Optimization of SOFC - GT Hybrid System Operational Characteristics
}

\author{
Yu Huang ${ }^{1 *}$, Ali Turan ${ }^{1}$ \\ ${ }^{1}$ School of Mechanical, Aerospace and Civil Engineering, The University of Manchester, \\ M1 7DN, Manchester, United Kingdom \\ *Corresponding author (Yu Huang) \\ Email address: yu.huang-7@postgrad.manchester.ac.uk
}

\begin{abstract}
The primary objective of this research is to analyze the effects of different fuels on the various performance characteristics of solid oxide fuel cell - gas turbine (SOFC - GT) hybrid systems and to optimize said component parameters based on relevant thermodynamic models. The hybrid system presented is that of a pressurized configuration containing a high temperature SOFC as well as a recuperator. For comparison, methane $\left(\mathrm{CH}_{4}\right)$, carbon monoxide $(\mathrm{CO})$ and hydrogen $\left(\mathrm{H}_{2}\right)$ are used to power SOFC - GT systems respectively, and when the system is fueled by $\mathrm{CH}_{4}$ or $\mathrm{CO}$, a reformer is also included in the system configuration. Results highlight the influence of different fuels and content on achievable operating range of SOFC and reformer temperature as well as on operating pressures; the system performance is also studied and compared in terms of potentials, electricity output, energy and exergy efficiency, etc. within the allowable range of parameters. It has been observed that the hybrid system reaches an optimized electric efficiency of $56.1 \%, 54.3 \%$ and $60.7 \%$ when fueled by $\mathrm{CH}_{4}, \mathrm{CO}$ and $\mathrm{H}_{2}$ (96 vol.\%) respectively based on this basic configuration proposed.
\end{abstract}

Keywords: SOFC - GT, hybrid system, fuel sensitivity, thermodynamic optimization, operating range

\section{Introduction}

According to statistical information provided by the International Energy Agency (IEA), electrical energy consumption is likely to see a $30 \%-35 \%$ increase from the current levels by 2050 [1]. To meet this demand without substantially degrading the environment, power producers are devoted to developing renewable energy sources, as well as novel energy conversion technologies. Solid oxide fuel cells (SOFCs), which transform chemical energy in fuels directly into electrical energy through electrochemical oxidization-reduction reactions, are not subjected to the Carnot efficiency limitations and are of low emissions [2,3]. Due to their high operating temperatures, SOFCs can be integrated 
with other bottoming cycles, such as a recuperative gas turbine (GT) cycle, to achieve even higher efficiency [4]. Although few industrial entities will produce SOFC - GT hybrid systems capable of producing hundreds of megawatts before cost, reliability and control issues are well addressed, micro gas turbine (mGT) technology can provide a promising intermediate solution to this type of hybridization $[5,6]$. Consistency of operation parameters between SOFCs and mGTs implies much simplification of system configurations and auxiliary equipment integration [7]. In addition, the SOFC - GT coupling technology possesses great flexibility in terms of system size and fuel selection. Such considerations further provide the background for the much attention received by such hybrid systems.

In recent years, great efforts have been made to achieve better designs of SOFC - GT hybrid systems. Modelling approaches of different complexity and assumptions have been adopted according to different objectives for these studies. Pirkandi et al. [8,9] established thermo-economic models to study the electricity generation prices, emission levels and efficiencies of natural gas fueled hybrid systems of different configurations, comprising one or two SOFC stacks. Zhao et al. [10] carried out a parametric optimization for a syngas-fueled hybrid system, and observed sensitivity of system performance to various operational parameters. In the research of Choudhary and Sanjay [3], the airfilm cooling technique of blades has been given serious consideration to achieve a more practical evaluation of the syngas-powered system. Results showed that the blade cooling technology can significantly influence the performance of the SOFC - GT system, and a maximum efficiency of $73.46 \%$ has been achieved for a turbine inlet temperature of $1600 \mathrm{~K}$ and a compression ratio of 20 . Facchinetti et al. [11] have performed energetic and exergetic analyses of SOFC - GT hybrid systems powered by hydrothermally gasified waste biomass, and found that the wet waste biomass can be converted into electricity at an optimized first law efficiency of $63 \%$ when an integrated configuration for fuel processing was adopted. Tarroja et al. [12] have conducted an extensive parametric analysis, in which a full suite of constraints resulting from modern material and operating limits were considered, to determine a more realistic design space for a hydrogen-fed SOFC - GT system.

In the studies mentioned above, different fuels have been selected to power their proposed hybrid systems respectively, while there are additional studies in the literature focusing on the impact of fuel changes on the performance of a given system. Yi et al. [13] investigated the use of NFCRC pipeline natural gas, diesel reformate, syngas derived from biogas and coal in the same integrated SOFC reformer system, and found that good operation on various fuels may not be achieved without significant changes in design and/or operational conditions. In the study of Li and Weng [14], a significant decrease in net power output and efficiency was observed when a methane-based SOFC GT hybrid system operated with "non-ideal" fuels, viz. hydrogen and ethanol. The net power output of hydrogen-fueled system could be improved to $94 \%$ of the methane-designed value, at the expense of a lower net efficiency of $45 \%$. Krummrein et al. [15] discussed the operating range and SOFC-offgas combustor requirements of a SOFC - mGT hybrid system fed with biogas containing various concentrations of methane. Harun et al. [16] explored dynamic response characteristics of SOFC when the hybrid system with a constant turbine speed experienced a drastic fuel composition change from coal-derived syngas to humidified methane.

Motivated by the desire for sustainable energy utilization, fuels from different sources and containing various components and concentrations will be continuously tested for SOFC - GT hybrid systems. 
Hence, it is absolutely necessary to develop a basic thermochemical fuel sensitivity methodology that allows for prediction of the particular system performance potential and any needed performance boosting technologies as influenced by composition and physicochemical properties of fuels. Based on the literature review, it can be seen that although some work has examined the effects of fuel composition changes (non-optimum fuels) on a given system for both transient and steady state performance, much work still remains to be done to compare the performance potential and necessary enhancement technologies of hybrid systems, highlighting fuel sensitivity issues in the light of accepted efficiency and exergetic considerations.

In the current work, methane $\left(\mathrm{CH}_{4}\right)$, carbon monoxide $(\mathrm{CO})$ and hydrogen $\left(\mathrm{H}_{2}\right)$ are employed to power a SOFC - GT hybrid system respectively, since they are the most common components in common fuels and syngas derived from different sources. The assessment of using these species is an essential first step to develop the methodology for performance prediction. Thermodynamic evaluation comprising established energy and exergy comparative framework has been carried out to investigate the sensitivity of core component and plant performance for these three fuels (common-species) and operational parameters. Achievable operating ranges based on proposed system configuration are analyzed with regard to available thermal energy for recovery. Performance improvement technologies, such as blade cooling and anode exhaust cycling, though not included in the present calculations, are discussed due to their potential incorporation in the system under different operating conditions. Optimized efficiencies of the SOFC - GT systems when fed with the three selected fuels are given based on parametric studies within their respective operating ranges. The effects of $\mathrm{CH}_{4} / \mathrm{CO}_{2} \mathrm{H}_{2}$ content in initial fuel on operating ranges and optimized performance are also investigated. Additional fuel species (such as carboxyl and alcoholic groups) and their possible combinations will be tested in future work according to the results of current research.

\section{The proposed hybrid system}

Fig. 1 shows the pressurized configuration of SOFC - GT hybrid systems considered in this work. Thermo-economic modelling studies from Pirkandi et al. [9] have found that such hybrid systems containing one pressurized SOFC is better than those with one atmospheric fuel cell or with two stack fuel cells when economic issues, such as purchase, installation and startup costs are major concerns. Although SOFCs have the potential to operate with different fuels, standard commercial SOFCs perform much more efficiently when fueled with $\mathrm{H}_{2}$ due to kinetic reasons [17]. Therefore, a reformer is located upstream of the SOFC anodic side to produce hydrogen-rich gases when $\mathrm{CH}_{4}$ or $\mathrm{CO}$ is employed to power the hybrid system.

On the cathodic end, atmospheric air is drawn into the compressor and gets pressurized. After compression, air flows through a recuperator, where it is pre-heated by the turbine exhaust gas. Then it is introduced to the cathode of the SOFC and reacts electrochemically with the hydrogen on the anodic side, converting chemical energy into electricity, as well as producing a substantial amount of thermal energy. The residual heat from SOFCs can be used to support the endothermic fuel processing reactions in the reformer [7, 18] and to heat up the compressed air and fuel. Exhausts from the SOFC are then diverted to an auxiliary combustor, in which further additional and unreacted fuel are burned to substantially increase the temperature of the turbine stream. High temperature exhaust gas from the 
combustor subsequently enters the turbine and expands to provide additional mechanical work. Part of the mechanical work is used to drive the compressors and the rest is converted into electric power through a generator. Exhaust gas from the turbine is routed through the hot side of recuperator, where the waste heat in the stream is recovered by transferring thermal energy to the air flow on the cold side, thereby improving the overall system efficiency.

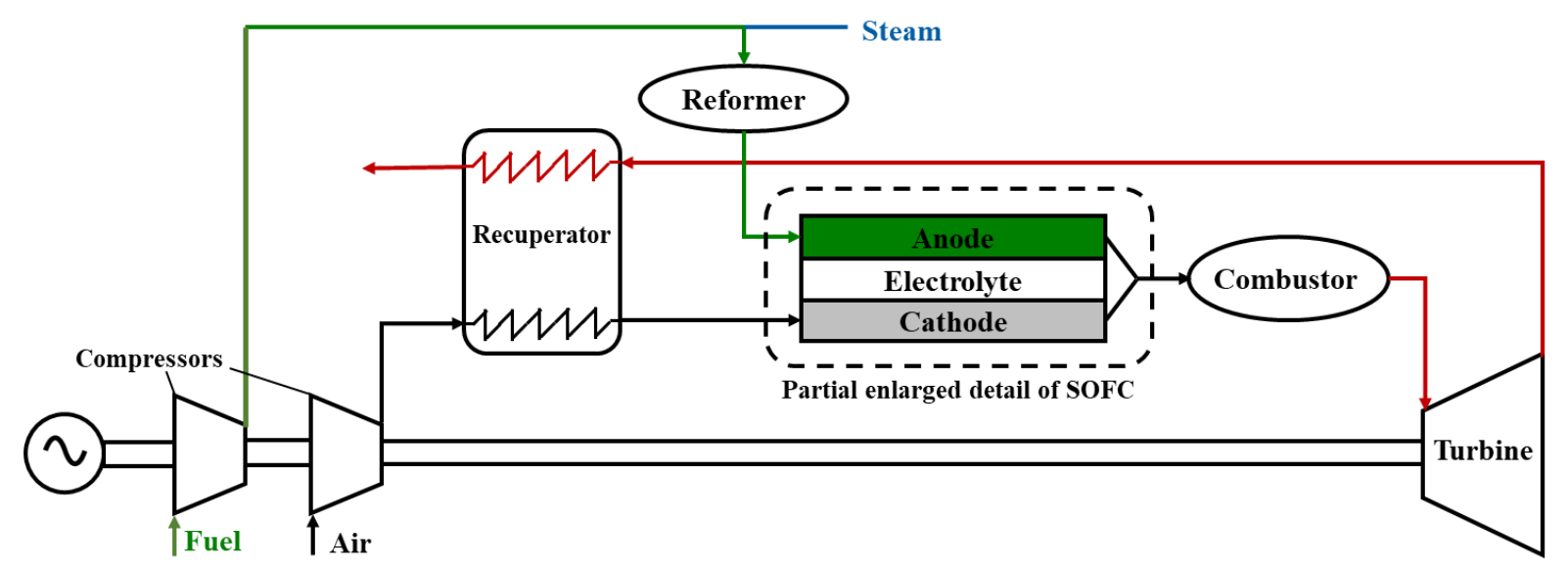

Fig. 1. Configuration of the SOFC-GT hybrid system

\section{Assumptions}

A mathematical model has been built in this study to evaluate the performance of proposed hybrid system. Thermal energy required for the fuel reforming reactions has been supplied directly from the SOFC generated heat. Hence, indirect internal reforming (IIR) SOFC configuration has been applied here, though the reformer is placed outside the SOFC in Fig. 1 and fuel treatment is analyzed separately from electrochemical reactions in the SOFC. The main simplifications and assumptions in this modelling study are listed as follows:

1. Mass leakage from the system has been disregarded.

2. Each component has been considered adiabatic.

3. The simulation has been conducted under steady state conditions.

4. Chemical reactions of fuel conversion in the reformer have reached equilibrium.

5. The temperature/pressure at anode and cathode outlets is equal to the cell temperature/pressure [18].

6. Exhaust gas from the reformer is assumed to be of the same temperature as inside the reformer.

7. Hydrogen is the only type of fuel taking part in electrochemical reactions in the SOFC.

8. Gases behave ideally in all components, meaning that the specific heat is a function of temperature and unaffected by pressure.

\section{Governing equations}

Table 1 Nomenclature

\begin{tabular}{|c|l|}
\hline$r_{S / C}$ & Steam to carbon ratio \\
\hline$A, B, C, D$ & Volumetric (molar) fractions of each component of fuel-steam mixture at reformer inlet \\
\hline$T$ & Temperature $(\mathrm{K})$ \\
\hline
\end{tabular}




\begin{tabular}{|c|l|}
\hline$p$ & Pressure (bar) \\
\hline$\Delta G_{T}^{\emptyset}$ & Gibbs free energy change of the electrochemical reaction at T and 1 bar \\
\hline$g_{i}\left(T, p^{\varnothing}\right)$ & Gibbs free energy of species i at temperature T and standard pressure \\
\hline$j$ & Current density $\left(\mathrm{A} / \mathrm{cm}^{2}\right)$ \\
\hline$V_{\text {conc }, a}, V_{\text {conc,c }}$ & Concentration overpotentials of SOFC anode and cathode $(\mathrm{V})$ \\
\hline$j_{L, a}, j_{L, c}$ & Limiting current density of anode and cathode, $0.9 \mathrm{~A} / \mathrm{cm}^{2}$ \\
\hline$I$ & Electric current $(\mathrm{A})$ \\
\hline$P_{S O F C}$ & Power produced by SOFC $(\mathrm{kW})$ \\
\hline$\dot{n}_{i}$ & Molar flow rate of species $\mathrm{i}(\mathrm{kmol} / \mathrm{s})$ \\
\hline$M_{i}$ & Relative molecular mass of species $\mathrm{i}(\mathrm{kg} / \mathrm{kmol})$ \\
\hline combin, combout & Inlet/outlet of the combustor \\
\hline$h$ & Molar specific enthalpy $(\mathrm{kJ} / \mathrm{kmol})$ \\
\hline$\eta_{t}, \eta_{c}$ & Adiabatic efficiency of the turbine, compressor \\
\hline$\dot{m}_{t}, \dot{m}_{\text {air }}$ & Total mass flow rate of through the turbine $(\mathrm{kg} / \mathrm{s})$, compressor $(\mathrm{kg} / \mathrm{s})$ \\
\hline$\overline{C_{p}}$ & Average isobaric heat capacity of gaseous mixture $(\mathrm{kJ} /(\mathrm{kg} \cdot \mathrm{K}))$ \\
\hline$\gamma_{t}, \gamma_{c}$ & Polytropic index of mixed gases at turbine inlet; air at compressor inlet, 1.4 \\
\hline comp $\mid$ in, comp $\mid$ out & Inlet/outlet of the compressor \\
\hline hot $\mid$ in, hot $\mid$ out & Recuperator hot side inlet and outlet \\
\hline cold $\mid$ in, cold $\mid$ out & Recuperator cold side inlet and outlet \\
\hline$F$ & Faraday's constant, $96485 \mathrm{kC} / \mathrm{kmol}$ \\
\hline$R$ & General gas constant, $8.3145 \mathrm{~kJ} /(\mathrm{kmol} \cdot \mathrm{K})$ \\
\hline LHV & Lower heating value of fuel $(\mathrm{kJ} / \mathrm{kmol})$ \\
\hline
\end{tabular}

\subsection{Reformer}

For the methane-fueled hybrid SOFC - GT system, the two main reactions taking place in the reformer are steam reforming (Eq. 1) and water-gas shift (Eq. 2). Unless otherwise specified, fuel stream consists of $96 \%$ methane $\left(\mathrm{CH}_{4}\right), 2 \%$ carbon dioxide $\left(\mathrm{CO}_{2}\right)$ and $2 \%$ nitrogen $\left(\mathrm{N}_{2}\right)$ by volume.

$$
\begin{aligned}
& \mathrm{CH}_{4}+\mathrm{H}_{2} \mathrm{O} \rightarrow \mathrm{CO}+3 \mathrm{H}_{2} \\
& \mathrm{CO}+\mathrm{H}_{2} \mathrm{O} \rightarrow \mathrm{CO}_{2}+\mathrm{H}_{2}
\end{aligned}
$$

If the volume fraction of converted $\mathrm{CH}_{4}$ is $x$ and that of reacted $\mathrm{CO}$ is $y$, the equilibrium constants of the two reactions can be expressed with partial pressures or corresponding molar fractions of the relevant components at equilibrium state (shown by Eq. 3 and Eq. 4). On the other hand, equilibrium constants can always be evaluated if the reaction temperature is known. Previous studies [19] have provided polynomial correlations to compute equilibrium constants for the two reactions taking place in the reformer (Eq. 5).

$$
\begin{gathered}
K_{p r}=\frac{P_{\mathrm{H}_{2}}{ }^{3} P_{\mathrm{CO}}}{P_{\mathrm{H}_{2} \mathrm{O}} P_{\mathrm{CH}_{4}}}=\frac{(3 x+y)^{3}(x-y)}{\left(A_{\mathrm{CH}_{4}}-x\right)\left(C_{\left.\mathrm{H}_{2} \mathrm{O}^{-}-y\right)}\right.}\left(\frac{P_{\text {reformer }}}{1+2 x}\right)^{2} \\
K_{p s}=\frac{P_{\mathrm{H}_{2} P_{\mathrm{CO}_{2}}}}{P_{\mathrm{CO} P_{\mathrm{H}_{2} \mathrm{O}}}}=\frac{(3 x+y)\left(B_{\mathrm{CO}_{2}}+y\right)}{(x-y)\left(C_{\mathrm{H}_{2} \mathrm{O}^{-x-y)}}\right.} \\
\log K_{p}=a_{1} T^{4}+a_{2} T^{3}+a_{3} T^{2}+a_{4} T+a_{5}
\end{gathered}
$$

The values of constants $\left(a_{1}, a_{2}, a_{3}, a_{4}, a_{5}\right)$ in Eq. 5 for steam reforming and water-gas shift reactions are 
listed in Table 2 respectively. With equilibrium constants $K_{p r}$ and $K_{p s}$ obtained, the volume percentage of reacted $\mathrm{CH}_{4}$ and $\mathrm{CO}$ ( $x$ and $y$ in Eq. 3 and Eq. 4) can be calculated, after which the volumetric composition of hydrogen-rich syngas at the outlet of the reformer (inlet of the SOFC anodic side) can be determined. Combining molar flow rate of initial fuel $\dot{N}$ (Table 5), steam to carbon ratio $r_{S / C}$ and changes in total molar number of gas caused by steaming reforming reaction (Eq. 1), the molar flow rate of each component at the SOFC anode inlet $\left(\dot{n}_{i \mid \text { SOFCin }}\right)$ can be further calculated.

Table 2 Values of polynomial coefficients in equilibrium constant calculation [19]

\begin{tabular}{|c|c|c|}
\hline Polynomial Coefficient & Steam Reforming & Water-gas Shifting \\
\hline$a_{1}$ & $-2.63121 \times 10^{-11}$ & $5.47301 \times 10^{-12}$ \\
\hline$a_{2}$ & $1.24065 \times 10^{-7}$ & $-2.57479 \times 10^{-8}$ \\
\hline$a_{3}$ & $-2.25232 \times 10^{-4}$ & $4.63742 \times 10^{-5}$ \\
\hline$a_{4}$ & 0.195028 & -0.03915 \\
\hline$a_{5}$ & -66.1395 & 13.2097 \\
\hline
\end{tabular}

When carbon monoxide (CO) is used as fuel, the most important reaction happening in the reformer is water-gas shift (Eq. 2). The volumetric composition of the original fuel is $96 \% \mathrm{CO}, 2 \% \mathrm{CO}_{2}$ and $2 \%$ $\mathrm{N}_{2}$ if not otherwise specified. Given that the reactions in the reformer have reached equilibrium, $K_{p s}$ can be expressed as Eq. 6, where $y$ represents the volume fraction of converted carbon monoxide.

$$
K_{p s}=\frac{P_{\mathrm{H}_{2}} P_{\mathrm{CO}_{2}}}{P_{\mathrm{CO}} P_{\mathrm{H}_{2} \mathrm{O}}}=\frac{\left(B_{\mathrm{CO}_{2}}+y\right) y}{\left(A_{\mathrm{CO}}-y\right)\left(C_{\mathrm{H}_{2}}-y\right)}
$$

\subsection{Nernst potential of SOFC}

Nernst potential is the open circuit voltage at specified temperature and pressure if the SOFC is assumed to operate reversibly, and can be computed according to Eq. 7, in which the three terms on the right-hand side are temperature, composition and pressure dependent respectively.

$$
E=E_{0}+\frac{R T}{2 F} \ln \left(\frac{\alpha \beta^{1 / 2}}{\gamma}\right)+\frac{R T}{4 F} \ln p_{S O F C}
$$

$E_{0}$ is the ideal open circuit voltage if the SOFC works at standard pressure ( 1 bar), and can be calculated using Eq. 8 and Eq. 9, according to the reaction in the SOFC (Eq. 10).

$$
\begin{gathered}
E_{0}=-\frac{\Delta G_{T}^{\emptyset}}{2 F} \\
\Delta G_{T}^{\emptyset}=g_{H_{2} O}\left(T, p^{\emptyset}\right)-g_{H_{2}}\left(T, p^{\emptyset}\right)-\frac{1}{2} g_{O_{2}}\left(T, p^{\emptyset}\right) \\
H_{2}+\frac{1}{2} O_{2} \rightarrow H_{2} O
\end{gathered}
$$

The second composition-dependent term contains volume fractions of hydrogen $\left(\mathrm{H}_{2}\right)$, oxygen $\left(\mathrm{O}_{2}\right)$ and steam $\left(\mathrm{H}_{2} \mathrm{O}\right)$, as shown by Eq. 11. Therefore, values of $\alpha$ and $\gamma$ can be determined by the volumetric composition of syngas at SOFC anode inlet. In the current work, air introduced into the compressor is assumed to consist of $79 \% \mathrm{~N}_{2}$ and $21 \% \mathrm{O}_{2}$ by volume.

$$
\begin{gathered}
P_{\mathrm{H}_{2}}=\alpha P_{\text {anode }}=\alpha P_{\text {cell }} \\
P_{O_{2}}=\beta P_{\text {cathode }}=\beta P_{\text {cell }}
\end{gathered}
$$




$$
P_{\mathrm{H}_{2} \mathrm{O}}=\gamma P_{\text {anode }}=\gamma P_{\text {cell }}
$$

For the hydrogen-powered SOFC - GT hybrid system, the original fuel flow is assumed to be volumetrically composed of $96 \% \mathrm{H}_{2}, 2 \% \mathrm{CO}_{2}$ and $2 \% \mathrm{~N}_{2}$, to make results more comparable.

\subsection{Voltage losses of SOFC}

Various operational losses one has to consider in the performance analysis of SOFC systems are incorporated in the model as per the recommendations of Turan et al. [7] with expressions signifying activation, ohmic and concentration considerations as standard. The actual operating voltage of the SOFC $\left(V_{o p}\right)$ is considerably less than the ideal Nernst voltage due to various irreversible factors within the device, as shown below:

$$
\begin{gathered}
V_{o p}=E-V_{\text {loss }} \\
V_{\text {loss }}=V_{\text {act }}+V_{\text {ohmic }}+V_{\text {conc }}
\end{gathered}
$$

\section{Activation-related losses $\left(V_{a c t}\right)$}

Activation-related losses are mainly caused by the activation energy required for the reaction to take place. It has been proved that current density has little influence on this type of losses, while they are more dependent on reactant activities, electrocatalyst materials as well as the microstructure [7]. Considering the relationship between activation energy and temperature (Arrhenius equation) and the fact that activation-related losses decrease with SOFC temperature increase, Eq. 14 is employed to evaluate this type of losses. Constants A and B are determined according to the work of $\mathrm{K}$. Tanaka et al. [20] that provided activation-related losses values at $1073 \mathrm{~K}$ and $1273 \mathrm{~K}$.

$$
V_{\text {act }}=\operatorname{Aexp}\left(\frac{B}{T}\right)
$$

\section{Ohmic losses $\left(V_{\text {ohmic }}\right)$}

Ohmic losses arise mainly due to the ionic resistance of electrolyte, the electronic resistance of interconnectors as well as the ionic and electronic resistance of electrodes. These losses grow linearly with current density, and are determined mainly by the material, structure and operating temperature of SOFCs [7]. The direction of electric current (positive charge) is shown in Fig. 2.

Table 3 Constants for resistivity calculation [21]

\begin{tabular}{|c|c|c|}
\hline $\boldsymbol{j}$ & $\boldsymbol{A}_{\boldsymbol{j}}(\Omega \cdot \mathrm{cm})$ & $\boldsymbol{B}_{\boldsymbol{j}}(\mathrm{K})$ \\
\hline Electrolyte & 0.00294 & 10350 \\
\hline Interconnector & 0.12 & 4690 \\
\hline Anode & 0.00298 & -1392 \\
\hline Cathode & 0.00811 & 600 \\
\hline
\end{tabular}

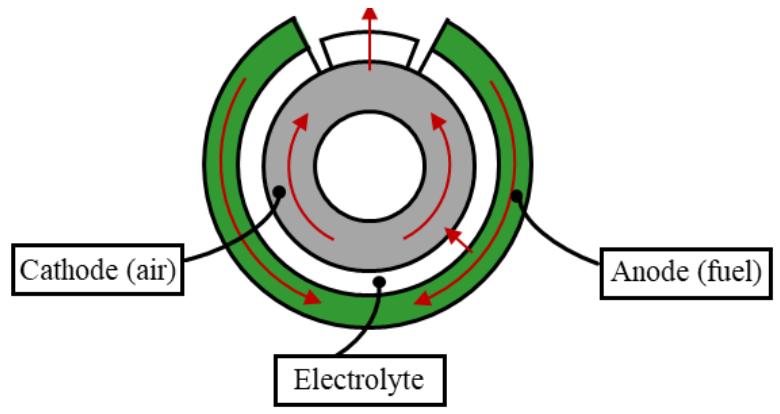

Fig. 2. Electric current in the SOFC

Combining Ohm's law and definitions of current density and resistivity, Eq. 15 can be derived to calculate ohmic voltage losses [20], in which $\rho_{e l e}, \rho_{i c}, \rho_{a n o}$ and $\rho_{c a t}$ are resistivity of electrolyte, interconnector, anode and cathode respectively.

$$
V_{\text {ohmic }}=j \rho_{\text {ele }} t_{\text {ele }}+j \pi D_{\text {cell }} \frac{\rho_{\text {ic }} t_{\text {ic }}}{w_{\text {ic }}}+j D_{\text {cell }} \frac{\pi}{2}\left(\frac{\rho_{\text {ano }}}{t_{\text {ano }}}+\frac{\rho_{\text {cat }}}{t_{\text {cat }}}\right) \frac{1}{2} D_{\text {cell }} \frac{\pi}{2}
$$




$$
\rho_{j}=A_{j} \exp \left(\frac{B_{j}}{T}\right)
$$

These resistivities can be computed from Eq. 16 [22], in which the constants $A_{j}$ and $B_{j}$ can be read from Table 3 for each element. The meaning and values of other parameters are listed in Table 4.

Table 4 Parameters for calculation of SOFC ohmic losses [20]

\begin{tabular}{|c|c|c|c|c|c|c|c|c|}
\hline & \multicolumn{2}{|c|}{ Electrolyte } & \multicolumn{2}{c|}{ Anode } & \multicolumn{2}{c|}{ Cathode } & \multicolumn{2}{c|}{ Interconnector } \\
\hline Thickness $(\mathrm{cm})$ & $t_{\text {ele }}$ & 0.002 & $t_{\text {ano }}$ & 0.01 & $t_{\text {cat }}$ & 0.02 & $t_{i c}$ & 0.002 \\
\hline Cell diameter $(\mathrm{cm})$ & \multicolumn{4}{|c|}{1.6} & Width, $w_{i c}(\mathrm{~cm})$ & 0.5 \\
\hline
\end{tabular}

\section{Mass-transport-related losses $\left(V_{\text {conc }}\right)$}

The non-ideal nature of SOFCs and the finite speed of reactants and products diffusion in these devices lead to concentration overpotentials. Normally, this mass-transport-related loss increases with current density growing, and can be evaluated according to Eq. 17 [10].

$$
V_{\text {conc }}=V_{\text {conc }, a}+V_{\text {conc }, c}=-\frac{R T}{2 F} \ln \left[\left(1-\frac{j}{j_{L, a}}\right)\left(1-\frac{j}{j_{L, c}}\right)\right]
$$

\subsection{Electric power output of SOFC}

Eq. 18 and 19 express the electrochemical reaction taking place at the anodic and cathodic side of the SOFC respectively. Hence, electric current can be calculated according to Eq. 20, based on which the electric power produced by the SOFC $\left(P_{S O F C}\right)$ is determined. Eq. 22 expresses the energy balance of the SOFC, and the term $Q_{r e s}$ represents the residual heat that can be used to support fuel reforming.

$$
\begin{gathered}
\mathrm{H}_{2}-2 e^{-}+\mathrm{O}^{2-} \rightarrow \mathrm{H}_{2} \mathrm{O} \\
\frac{1}{2} \mathrm{O}_{2}+2 e^{-} \rightarrow \mathrm{O}^{2-} \\
I=\dot{n}_{\mathrm{H}_{2} \text {,reacted }} \times 2 \times F \times 1000=\dot{n}_{\mathrm{O}_{2}, \text { reacted }} \times 4 \times F \times 1000 \\
P_{\text {SOFC }}=V_{\text {op }} \times I / 1000 \\
\dot{H}_{\text {SOFCout }}=\dot{H}_{\text {SOFCin }}-\left(P_{\text {SOFC }}+Q_{\text {res }}\right)
\end{gathered}
$$

The supply of the original fuel in this study is set at $\dot{N}=15 \mathrm{kmol} / \mathrm{h}$. Then the total molar flow rate at SOFC anode inlet can be determined with considerations of the steam supplied and the volume change due to steam-reforming reaction if necessary. Combined with the molar composition of syngas at reformer outlet (SOFC inlet), the amount of reacted hydrogen can be obtained from Eq. 23.

$$
\dot{n}_{H_{2}, \text { reacted }}=U_{f} \cdot \dot{n}_{H_{2} \mid \text { SOFCin }}
$$

\subsection{Air supply Calculation}

According to Eq. 18 and Eq. 19, the amount of reacted oxygen should be half of that of hydrogen. However, due to the incomplete reactions of oxygen, it is usually supplied excessively (Eq. 24). Therefore, air introduced into the system can be determined using Eq. 25 and Eq. 26 respectively.

$$
\begin{gathered}
\dot{n}_{O_{2}, \text { supplied }}=\dot{n}_{O_{2}, \text { reacted }} / U_{A} \\
\dot{n}_{\text {air, supplied }}=\dot{n}_{O_{2}, \text { supplied }} / 0.21
\end{gathered}
$$




$$
\dot{m}_{\text {air }}=\dot{n}_{\text {air }, \text { supplied }} \times\left(0.21 \times M_{O_{2}}+0.79 \times M_{N_{2}}\right)
$$

After the electrochemical reaction in SOFC and mixing of exhausts from anodic and cathodic sides, the molar flow rate of each component of stream at SOFC outlet (combustor inlet) can be determined with $\quad \dot{n}_{H_{2} \mid \text { combin }}=\dot{n}_{H_{2} \mid \text { SOFCin }}-\dot{n}_{H_{2}, \text { reacted }} \quad, \quad \dot{n}_{O_{2} \mid \text { combin }}=\dot{n}_{O_{2} \text {, supplied }}-\dot{n}_{O_{2}, \text { reacted }} \quad, \quad \dot{n}_{H_{2} O \mid \text { combin }}=$ $\dot{n}_{\mathrm{H}_{2} \mathrm{O} \mid \text { SOFCin }}+\dot{n}_{\mathrm{H}_{2} \text {,reacted }}, \quad \dot{n}_{\mathrm{N}_{2} \mid \text { combin }}=\dot{n}_{\mathrm{N}_{2} \mid \text { SOFCin }}+0.79 \dot{n}_{\text {air }, \text { supplied }}$ and $\dot{n}_{i \mid \text { combin }}=\dot{n}_{i \mid \text { SOFCin }}$ (for any other components).

\subsection{Combustor}

Remaining combustible components $\left(\mathrm{CH}_{4}, \mathrm{CO}\right.$ and $\mathrm{H}_{2}$ for methane-fueled hybrid system, $\mathrm{CO}$ and $\mathrm{H}_{2}$ for carbon monoxide-fueled one and $\mathrm{H}_{2}$ for hydrogen-fueled one) are burned completely in the combustor. Based on the corresponding combustion reactions (Eq. $27-29)$ and the mass conservation law, molar flow rates of each component at the outlet of combustor $\dot{n}_{i \mid c o m b o u t}$ can be determined.

$$
\begin{gathered}
\mathrm{CH}_{4}+2 \mathrm{O}_{2} \rightarrow \mathrm{CO}_{2}+2 \mathrm{H}_{2} \mathrm{O} \\
\mathrm{CO}+\frac{1}{2} \mathrm{O}_{2} \rightarrow \mathrm{CO}_{2} \\
\mathrm{H}_{2}+\frac{1}{2} \mathrm{O}_{2} \rightarrow \mathrm{H}_{2} \mathrm{O}
\end{gathered}
$$

The temperature of combustor exhaust $\left(T_{\text {combout }}\right)$ can be determined with an iterative algorithm. Assuming the combustion is adiabatic with efficiency of $100 \%$, the enthalpy before and after combustion remains the same (Eq. 30). According to mass conservation of chemical reactions, the total mass flow rate through the SOFC, combustor and turbine $\left(\dot{m}_{t}\right)$ are equal, although the gas flow is of different molecular compositions at different locations, leading to several computational expressions of the mass flow rate (Eq. 31).

$$
\begin{gathered}
\sum_{i} \dot{n}_{i \mid \text { combin }} h_{i}\left(T_{\text {combin }}\right)=\sum_{j} \dot{n}_{j \mid \text { combout }} h_{j}\left(T_{\text {combout }}\right) \\
\dot{m}_{t}=\sum_{i} \dot{n}_{i \mid \text { combin }} M_{i}=\sum_{j} \dot{n}_{j \mid \text { combout }} M_{j}=\dot{m}_{\text {air }}+\sum_{k} \dot{n}_{k \mid \text { SOFCin }} M_{k}
\end{gathered}
$$

\subsection{Turbine}

Total mechanical work produced by the turbine $\left(W_{t}\right)$ can be calculated according to Eq. 32, in which $T_{\text {tur } i \text { in }}$ and $p_{\text {tur } i n}$ represent the temperature and pressure of flow at turbine inlet and can be determined from combustor model. Pressure at the turbine outlet ( $p_{\text {tur|out }}$ ) should be the sum of ambient pressure ( 1 bar) and the pressure loss of recuperator. The temperature at turbine outlet is determined by Eq. 33.

$$
\begin{gathered}
W_{t}=\dot{m}_{t} \cdot \overline{C_{p \mid t}} \cdot \eta_{t} \cdot T_{\text {tur|in }}\left[1-\left(\frac{p_{\text {tur } \mid \text { out }}}{p_{\text {tur } \mid \text { in }}}\right)^{\frac{\gamma_{t}-1}{\gamma t}}\right] \\
T_{\text {tur|out }}=T_{\text {tur|in }}-W_{t} /\left(\dot{m}_{t} \overline{C_{p \mid t}}\right)
\end{gathered}
$$

\subsection{Compressor}

The work required by the air compression process is calculated according to Eq. 34, where the pressure at the outlet of the compressor $\left(p_{\text {comp } \mid \text { out }}\right)$ should be the sum of SOFC pressure $\left(P_{C e l l}\right)$ and the pressure loss of recuperator. The temperature at the outlet of the compressor is determined by Eq. 35. The compression process of fuel can be calculated in similar way. 


$$
\begin{gathered}
W_{c}=\dot{m}_{\text {air }} \cdot \overline{C_{p \mid a i r}} \cdot \frac{T_{c o m p \mid i n}}{\eta_{c}} \cdot\left[\left(\frac{p_{c o m p \mid o u t}}{p_{c o m p \mid i n}}\right)^{\frac{\gamma_{c}-1}{\gamma_{c}}}-1\right] \\
T_{\text {comp|out }}=T_{\text {comp|in }}+W_{c} /\left(\dot{m}_{\text {air }} \overline{C_{p \mid a l r}}\right)
\end{gathered}
$$

\subsection{Recuperator}

Recuperator is a heat exchange device recovering the residual heat of the turbine exhausts and preheating pressurized air simultaneously. The effectiveness of recuperator $(\varepsilon)$ is defined as Eq. 36. The stream temperature at hot side outlet $\left(T_{\text {hot } \mid \text { out }}\right)$ is computed according to energy conservation (Eq. 37).

$$
\begin{gathered}
\epsilon=\frac{T_{\text {cold } \mid \text { out }}-T_{\text {cold } \mid \text { in }}}{T_{\text {hot } \mid \text { in }}-T_{\text {cold } \mid \text { in }}} \\
\dot{m}_{\text {air }} \overline{C_{p, \text { cold }}}\left(T_{\text {cold } \mid \text { out }}-T_{\text {cold } \mid \text { in }}\right)=\dot{m}_{t} \overline{C_{p, \text { hot }}}\left(T_{\text {hot } \mid \text { in }}-T_{\text {hot } \mid \text { out }}\right)
\end{gathered}
$$

\subsection{Specific work and electric efficiency}

The net mechanical work $\left(W_{n e t}\right)$ produced by SOFC-GT hybrid systems is calculated according to Eq. 38, and the electric efficiency $\left(\eta_{\text {ele }}\right)$ is evaluated using Eq. 39. Specific electric work is obtained by dividing net electric power with total mass flow rate through turbine $\left(m_{t}\right)$.

$$
\begin{aligned}
& \dot{W}_{\text {net }}=\dot{W}_{t}-\dot{W}_{c} \\
& \eta_{\text {ele }}=\frac{P_{S O F C}+\dot{W}_{\text {net }} \eta_{g e}}{\frac{\dot{N}}{3600} \times 96 \% \times L H V}
\end{aligned}
$$

\subsection{Exergy efficiency of individual components}

The exergy efficiency of the SOFC and SOFC-reformer integrated system are calculated according to Eq. $40-41$.

$$
\begin{aligned}
\eta_{\text {ex } \mid S O F C} & =\frac{P_{S O F C}}{\dot{E}_{a n o}+\dot{E}_{c a t}-\dot{E}_{S O F C \mid o u t}} \\
\eta_{\text {ex } \mid S O F C-r e f} & =\frac{P_{S O F C}}{\dot{E}_{\text {refin }}+\dot{E}_{\text {cat }}-\dot{E}_{S O F C \mid o u t}}
\end{aligned}
$$

\section{Validation}

Based on governing equations for individual components discussed above a MATLAB code has been develop to evaluate specific performance of SOFC - GT hybrid systems powered by methane, carbon monoxide and hydrogen respectively. The constant parameters and default values (if not otherwise specified) for some variable parameters are listed in Table 5. To validate the established model, the system proposed in Nien's work [7, 23] has been calculated using the written code with parameter values set the same. The results obtained from the developed code have been compared with their calculation (Table 6), and they show close agreement. The reason for the difference in voltage is that Nien et al. had used a correlation equation at temperature of $1273 \mathrm{~K}$ while in the present research a temperature-related equation (Eq. 17) [10] has been used to estimate the concentration overpotentials.

Table 5 Assumed parameter values of hybrid systems

\begin{tabular}{|l|l|l|l|}
\hline Molar flow rate of fuel, $\dot{N}(\mathrm{kmol} / \mathrm{h})$ & 15 & Adiabatic efficiency of turbine & 0.85 \\
\hline
\end{tabular}




\begin{tabular}{|l|c|l|c|}
\hline Pressure loss of SOFC & 0.03 & Current density, $\mathrm{j}(\mathrm{A} \cdot \mathrm{cm})$ & 0.3 \\
\hline Pressure loss of combustor & 0.05 & Adiabatic efficiency of compressor & 0.75 \\
\hline Pressure loss of recuperator & 0.02 & Adiabatic efficiency of fuel compressor & 0.75 \\
\hline Fuel utilization $U_{f}$ & 0.8 & Efficiency of generator & 0.95 \\
\hline Air utilization $U_{A}$ & 0.3 & Recuperator effectiveness & 0.6 \\
\hline
\end{tabular}

Table 6 Comparison of results from developed code and Nien's [23] calculation

\begin{tabular}{|l|l|l|}
\hline Compared parameters & $\begin{array}{l}\text { Results from } \\
\text { Nien [20] }\end{array}$ & $\begin{array}{l}\text { Results obtained from } \\
\text { written code }\end{array}$ \\
\hline Operational voltage & $0.65 \mathrm{~V}$ & $0.58 \mathrm{~V}$ \\
\hline Air flow rate & $1.8148 \mathrm{~kg} / \mathrm{s}$ & $1.7000 \mathrm{~kg} / \mathrm{s}$ \\
\hline Total electric power & $1.463 \mathrm{MW}$ & $1.3847 \mathrm{MW}$ \\
\hline System efficiency & $60.56 \%$ & $60.15 \%$ \\
\hline
\end{tabular}

\section{Results and discussions}

\subsection{Effects of steam to carbon ratio}

\section{Effects on syngas compositions}

Fig. 3 shows how the volumetric composition of processed fuel changes with steam to carbon ratio $\left(r_{S / C}\right)$. In methane $\left(\mathrm{CH}_{4}\right)$ fueled hybrid system, the volumetric proportion of hydrogen $\left(\mathrm{H}_{2}\right)$ is around $55 \%$. Although the molar fraction of $\mathrm{H}_{2}$ does not change much, considering more steam enters the reformer, the absolute yield of $\mathrm{H}_{2}$ actually increases substantially. In the carbon monoxide (CO) fueled system, there is a similar but more obvious trend in the volume fraction of $\mathrm{H}_{2}$, increasing from $33 \%$ to $46 \%$ as $\mathrm{r}_{\mathrm{S} / \mathrm{C}}$ grows from 0.5 to 1.0 , and then decreasing to $39 \%$. This is because more steam entering the reformer firstly promotes the production of hydrogen, and then dilutes the concentration of hydrogen because of excessive steam.

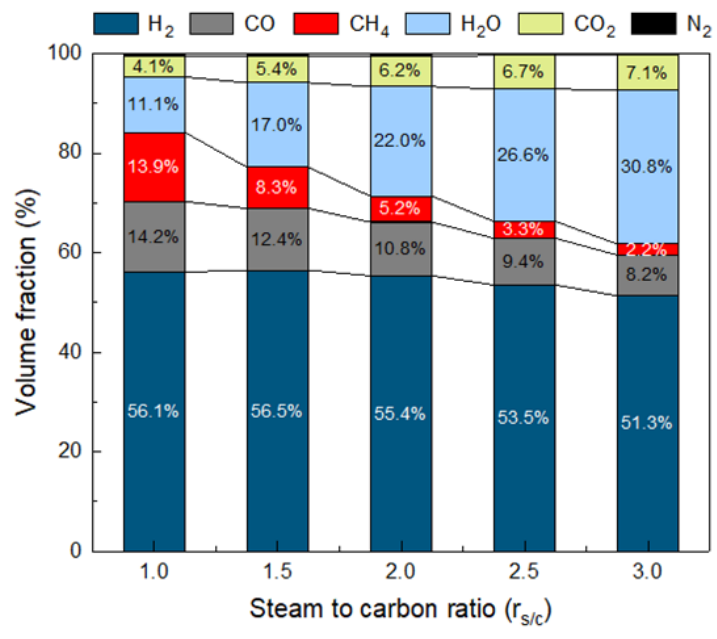

(a) Methane fueled

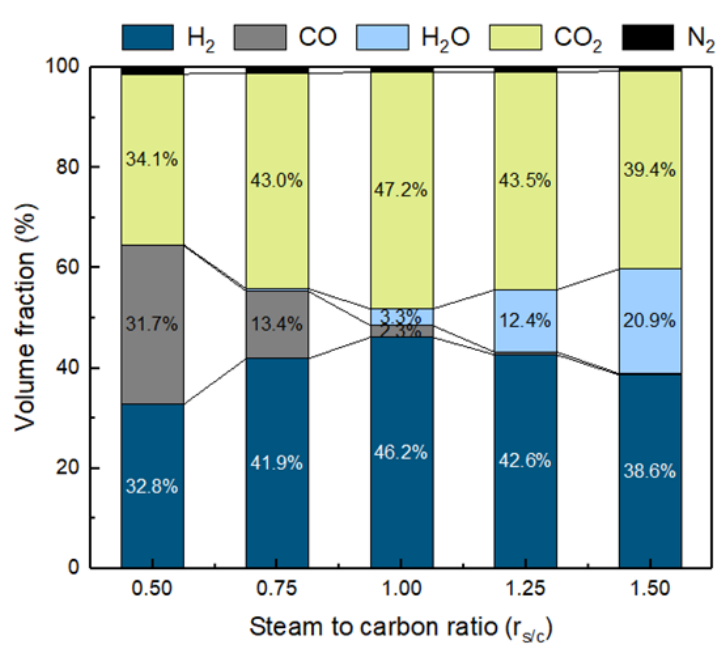

(b) Carbon monoxide fueled

Fig. 3. Effects of steam to carbon ratio on syngas compositions 


\section{Effects on SOFC-reformer exergy efficiency and overall efficiency}

Fig. 4a presents the effect of steam to carbon ratio on the exergy efficiency of SOFC-reformer integrated systems, which are quite different for hybrid systems powered by different fuels. For the $\mathrm{CH}_{4}$ fueled system, the exergy efficiency sees a sharp increase from $59.0 \%$ to $75.7 \%$ as $r_{S / C}$ varied from 0.75 to 2.00 , after which it continues to grow but more moderately to $79.4 \%$. This is because in the selected range of steam to carbon ratio, a higher $r s / C$ corresponds to a higher conversion rate of $\mathrm{CH}_{4}$, as shown in Fig. 3a, therefore leading to a larger amount of reacted $\mathrm{H}_{2}$ and $\mathrm{SOFC}$ electric power output. When powered with CO, SOFC-reformer exergy efficiency is firstly improved from $65.7 \%$ to $72.7 \%$ when $r S / C$ increases from 0.50 to 0.75 , and then drops to around $65 \%$. Carbon monoxide is almost completely converted when $r_{S / C}$ reaches 1.00 (Fig. 3b). The further increase in $r_{S / C}$ causes a significant decrease in the voltage (Fig. 5a), while no more $\mathrm{H}_{2}$ is reacted, leading to the decline in SOFC-reformer exergy efficiency. Slight increase in exergy efficiency is observed again when $r_{S / C}$ gets higher than 2.00 due to the exothermic characteristics of water-gas shift and electrochemical reactions, as more thermal energy is recovered by heating up excessive steam to the temperature of SOFC.

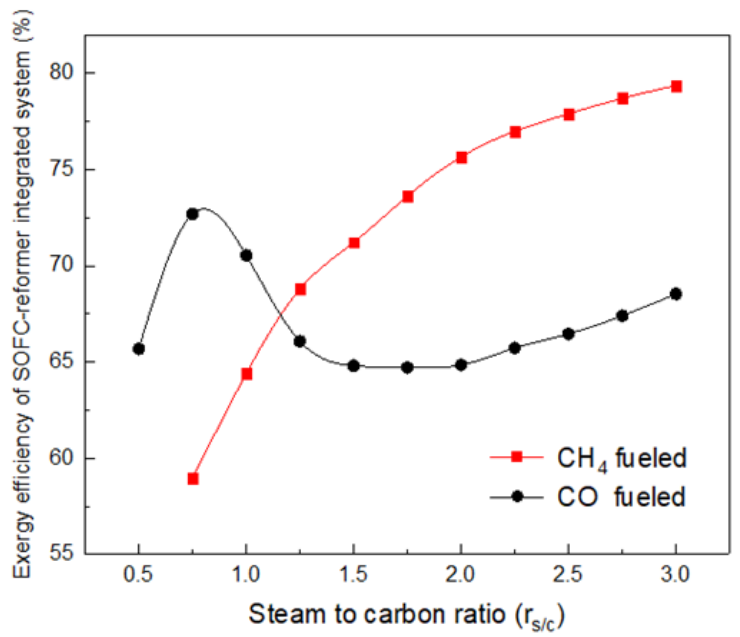

(a) SOFC-reformer exergy efficiency

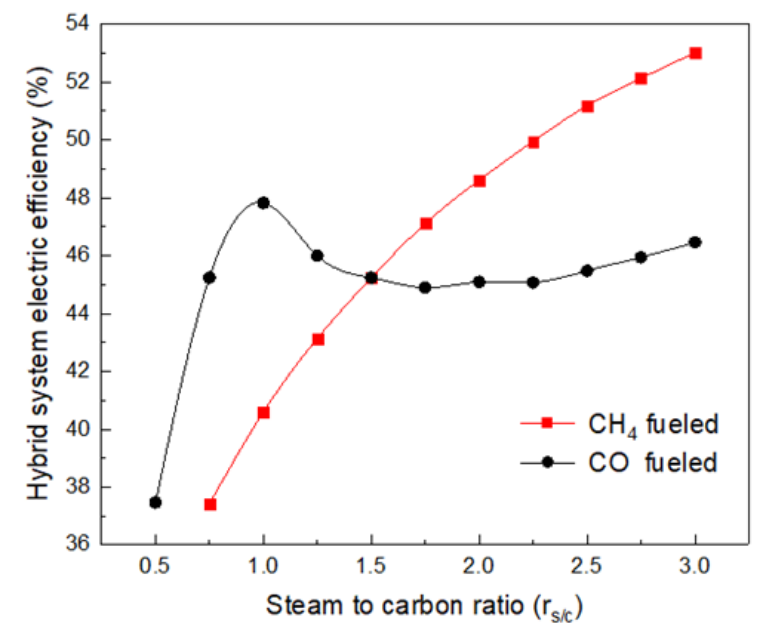

(b) Hybrid system electric efficiency

Fig. 4. Effects of steam to carbon ratio on SOFC-reformer exergy efficiency \& overall efficiency

The electric efficiency of the overall hybrid system shows a very similar trend, as shown in Fig. 4b, because electric power produced by SOFCs comprises a large proportion of the total electric power output. When $r s / C$ grows, more original fuel is converted into $\mathrm{H}_{2}$ and reacted electrochemically in the SOFC, instead of being burned in the combustor, which is beneficial to overall electric efficiency improvement. With $r_{S / C}$ increasing further, the electric efficiency of CO-powered hybrid system does not decline as much as exergy efficiency, because the total mechanical work produced by the turbine increases as the total mass flow rate becomes larger.

\section{Effects on Nernst potential and specific electric work}

Fig. 5 shows that both Nernst potential and specific electric work drop with an increasing steam to carbon ratio, though these performance indicators are more sensitive to $r_{S / C}$ when the hybrid system is powered by $\mathrm{CO}$, especially in the $r_{S / C}$ range of $0.50 \sim 1.50$. The reason for such declines is that $r_{S / C}$ changes the volume fractions of $\mathrm{H}_{2}$ and $\mathrm{H}_{2} \mathrm{O}$ in the flow entering the SOFC anodic side (Fig. 3). 
Considering the second term on the right-hand side of Eq. 7, which describes concentration impacts, Nernst potential declines with lower content of $\mathrm{H}_{2}$ and higher content of $\mathrm{H}_{2} \mathrm{O}$. Specific electric work decreases mainly because the rise in total electric work (from the SOFC and the generator) cannot compensate for the influence caused by the increase in total gas amount. When $\mathrm{CH}_{4}$ is used as the original fuel the specific electric work is considerably larger, meaning more electricity can be produced with the same system scales.

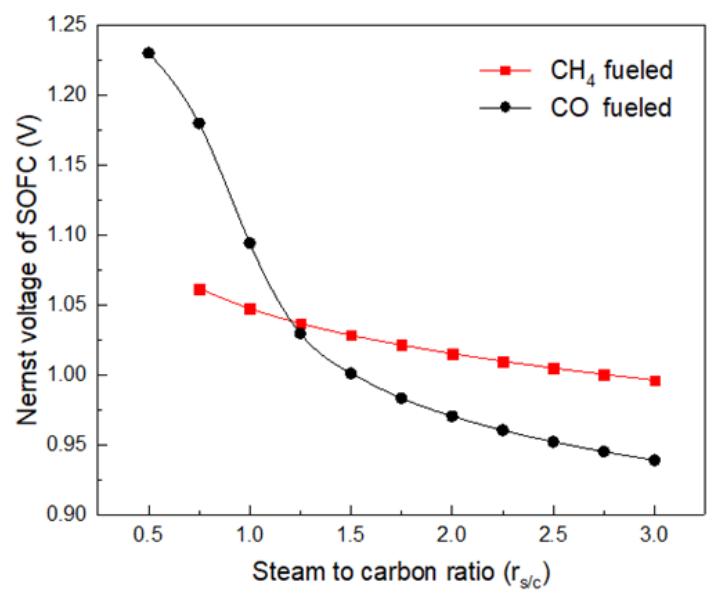

(a) Nernst voltage of SOFCs

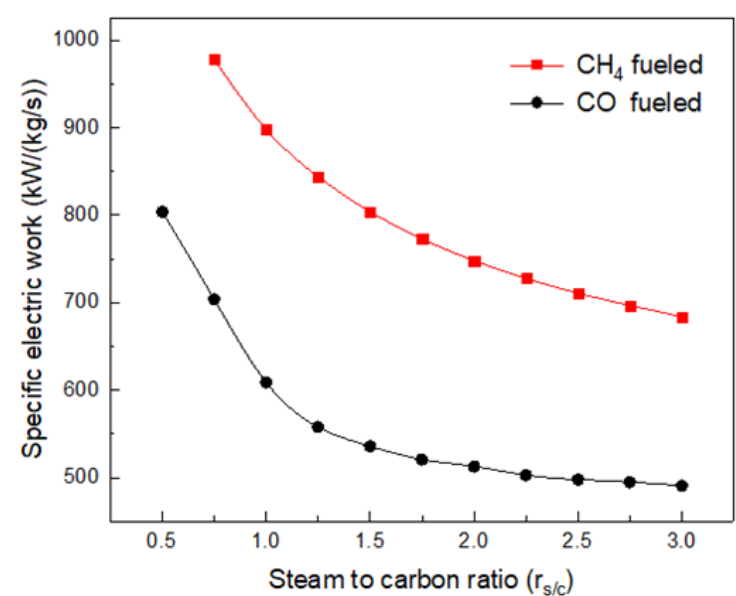

(b) Specific electric work

Fig. 5. Effects of steam to carbon ratio on Nernst voltage and specific electric work

Based on comprehensive consideration, $r_{S / C}=2.00$ and $r s / C=1.00$ is selected for $\mathrm{CH}_{4}$ powered system and $\mathrm{CO}$ powered system respectively to achieve acceptable efficiencies and conversion rates of the original fuel without too much potential and specific work drops.

\subsection{Operating temperatures of SOFCs and reformers}

Due to different characteristics of fuel conversion reactions, the operating range and selection of SOFC and reformer temperature are very different when hybrid systems are powered by various original fuels. In this section, achievable operating temperature range based on proposed system configuration, and the influence of SOFC and reformer temperature are discussed for methane, carbon monoxide and hydrogen fueled hybrid systems respectively.

\section{Methane-fueled hybrid system}

The overall effect of steam reforming (Eq. 1) and water-gas shifting (Eq. 2) reactions is usually heat consuming [17] so higher reformer temperatures can promote the conversion of $\mathrm{CH}_{4}$ and the generation of $\mathrm{H}_{2}$. Thermal energy required for heating up pressurized fuel to reformer temperature and for endothermic methane conversion reactions, namely heat needed by the reformer, is from SOFC heat release based on proposed system (Fig. 1). SOFC residual heat in this work refers to the part that can be used to support the reformer, which means the heat required for heating anodic and cathodic inlet streams to SOFC temperature has been subtracted.

The operating range of reformer temperature depends on the relationship between SOFC residual heat and heat required by the reformer, as shown in Fig. 6. A larger amount of thermal energy is required when the reformer operates at higher temperature because both preheating of compressed fuel and 
higher $\mathrm{CH}_{4}$ conversion consume more heat. The residual heat from SOFC declines with SOFC temperature rising as more thermal energy is consumed to heat streams from the recuperator and the reformer. The reformer has a corresponding maximum operating temperature, at which SOFC residual heat just supports the reformer, for different operating temperatures of the SOFC.

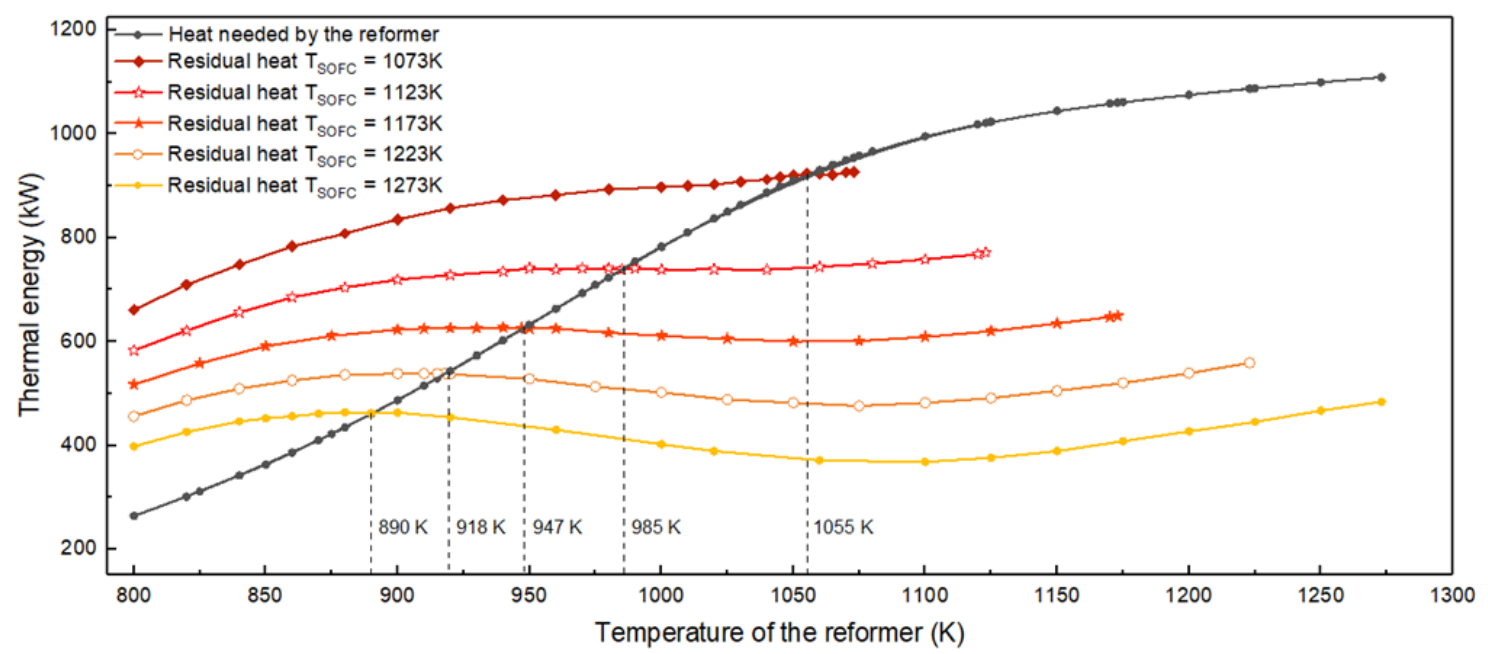

Fig. 6. Thermal energy released and required $\left(p_{S O F C}=4 \mathrm{bar}\right)$

Fig. 7 presents how exergy efficiency changes within the achievable reformer temperature range when the SOFC operates at different temperatures. It can be seen that exergy efficiencies of both SOFC and SOFC-reformer integrated system increase with higher reformer temperature, and the integrated system shows higher exergy efficiency than separate SOFC component. This indicates that full utilization of residual heat from SOFC, or other components, is very important for system performance.

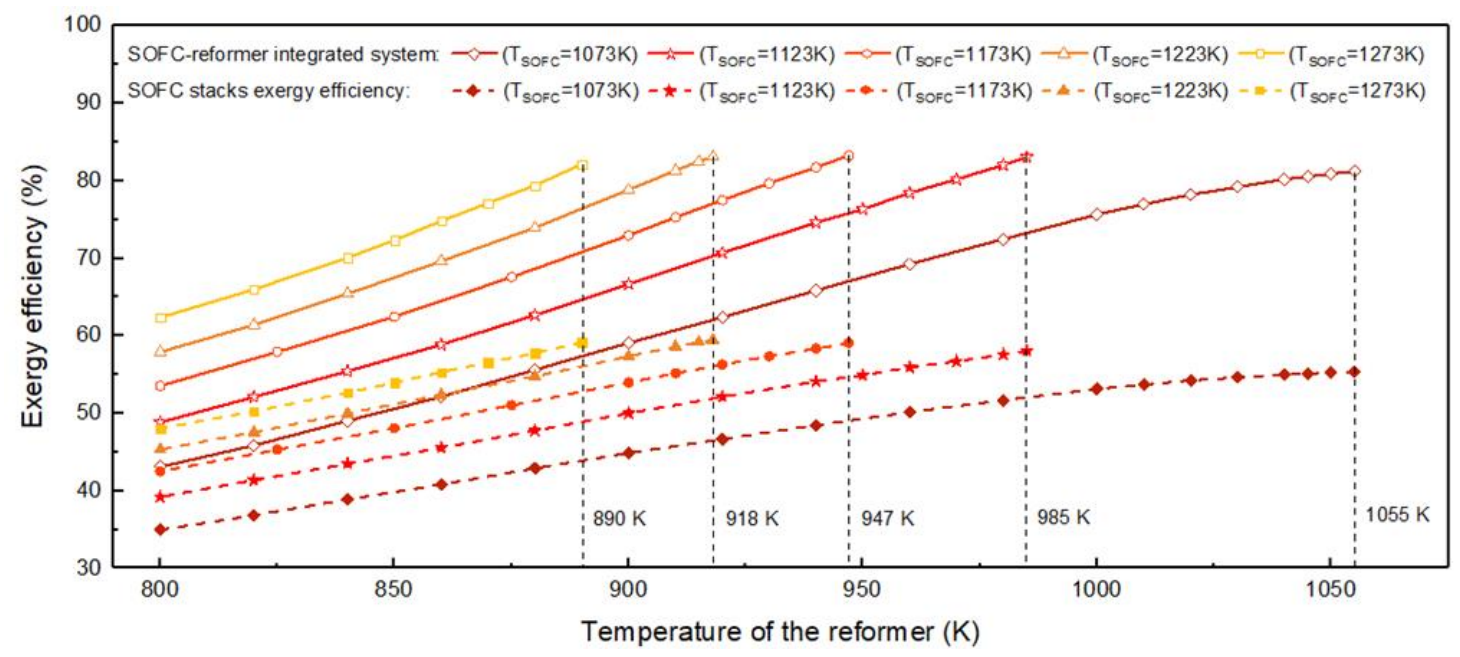

Fig. 7. Exergy efficiency of SOFC and SOFC-reformer integrated system $\left(p_{S O F C}=4 \mathrm{bar}\right)$

Although the whole hybrid system can achieve better electric efficiency with higher SOFC temperature when the reformer temperature is kept constant, relatively lower SOFC temperature gives wider operating range of reformer temperature, and the highest hybrid system electric efficiency of $53.0 \%$ is achieved at SOFC temperature of $1073 \mathrm{~K}$ and reformer temperature of $1055 \mathrm{~K}$ (Fig. 8). 


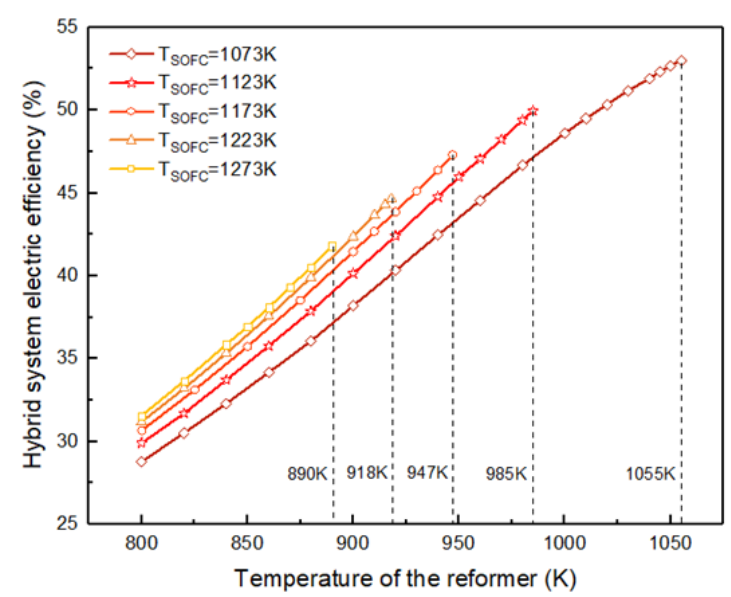

Fig. 8. Effects of reformer temperatures on hybrid system electric efficiency $\left(p_{S O F C}=4 \mathrm{bar}\right)$

\section{Carbon monoxide/hydrogen fueled hybrid system}

The water-gas shifting reaction (Eq. 2) is exothermic so high reformer temperatures can lead to low $\mathrm{CO}$ conversion. Hence, the reformer operates at the temperature equal to that of pressurized fuel when the hybrid system is fueled with $\mathrm{CO}$, and the thermal energy released by $\mathrm{CO}$ conversion and electrochemical reactions can be used to heat SOFC inlet streams to the operating temperature of SOFC. Similarly, in $\mathrm{H}_{2}$ powered system the heat generated by electrochemical reactions can be used to increase the temperature of compressed fuel and air flows. Fig. 9 shows residual heat of SOFCreformer integrated system for CO-fueled system and that of SOFC for $\mathrm{H}_{2}$-fueled system.

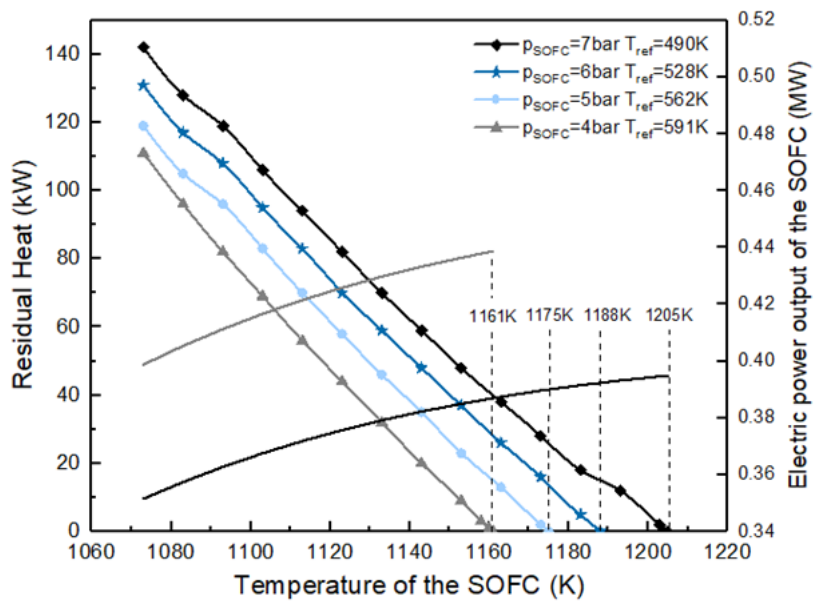

(a) Carbon monoxide fueled

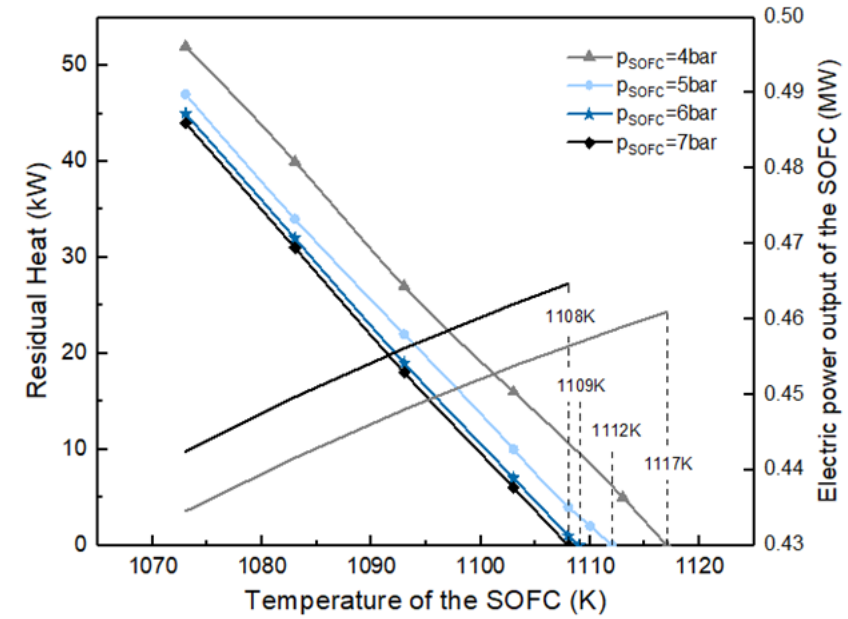

(b) Hydrogen fueled

Fig. 9. Residual heat of SOFC-reformer at different temperatures and pressures

There is a corresponding maximum operating temperature of SOFC for different compression ratios, based on the proposed system configuration. It is worth noting that the achievable maximum SOFC temperature increases with higher SOFC pressures in CO-fueled system, while larger compression ratios correspond to lower operating ranges of SOFC temperature in hybrid system powered with $\mathrm{H}_{2}$. As compression ratios increase, the enthalpy of fuel stream at the reformer (or SOFC when $\mathrm{H}_{2}$ is used) inlet rises. For CO fueled system, the electricity output of SOFC decreases with higher pressures (Fig. 9a), which leads to larger amount of enthalpy at SOFC outlet corresponding to higher SOFC 
temperature. On the contrary, the SOFC electricity output increases with higher pressures and the increase is more influential than SOFC inlet enthalpy increase when $\mathrm{H}_{2}$ is used. This leads to lower enthalpy at SOFC outlet corresponding to lower temperature operating range of SOFC considering energy conservation.

\subsection{Effects of operating pressures}

The operating pressure of the reformer is the same as that of SOFC in this study. This section presents information on how operating pressures can affect the temperature operating ranges of reformers and SOFCs, as well as the electric efficiency of the whole hybrid systems.

\section{Methane-fueled hybrid system}

The reformer requires less heat energy at higher operating pressures, as shown in Fig. 10a, because more compression work done to the fuel stream increases the temperature of reformer inlet flow, and methane conversion, which is endothermic, drops at higher pressures. Hence, the achievable operating temperature range of reformer extends to higher temperatures (Fig. 10b). The overall electric efficiency of hybrid systems at different SOFC temperatures and operating pressures is presented in Fig. 11, when the reformer operates at the highest allowable operating temperatures so that the highest electric efficiency at a certain $p_{S O F C}$ and $T_{S O F C}$ can be obtained (Fig. 8).

The optimized SOFC temperature and operating pressure based on proposed system is $1073 \mathrm{~K}$ and 7 bar, giving a hybrid system electric efficiency of 56.1\% when the reformer operates at the corresponding maximum achievable temperature of $1070 \mathrm{~K}$. In this case, an acceptable $\mathrm{CH}_{4}$ conversion of $82.4 \%$ and turbine inlet temperature of $1656 \mathrm{~K}$ have been achieved. However, anode exhaust cycling becomes necessary for methane conversion promotion and turbine inlet temperature (TIT) control when SOFC operates at higher temperatures. Blade cooling technology also needs to be considered with high SOFC operating temperatures. It is worth noting that the exhaust at recuperator hot-side outlet still contains large amounts of thermal energy. Reasonable use of this part of energy will help extend the achievable temperature range of reformer, thus bringing improvements in various performance indicators.

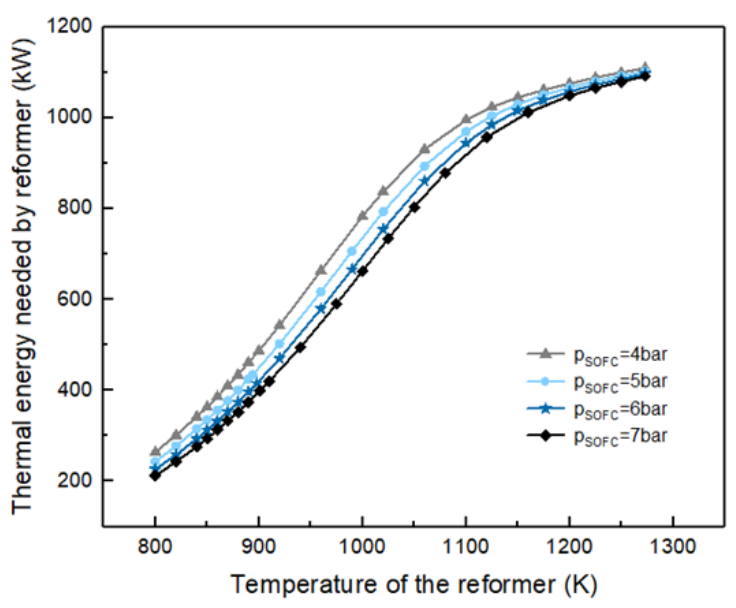

(a) Heat required by the reformer

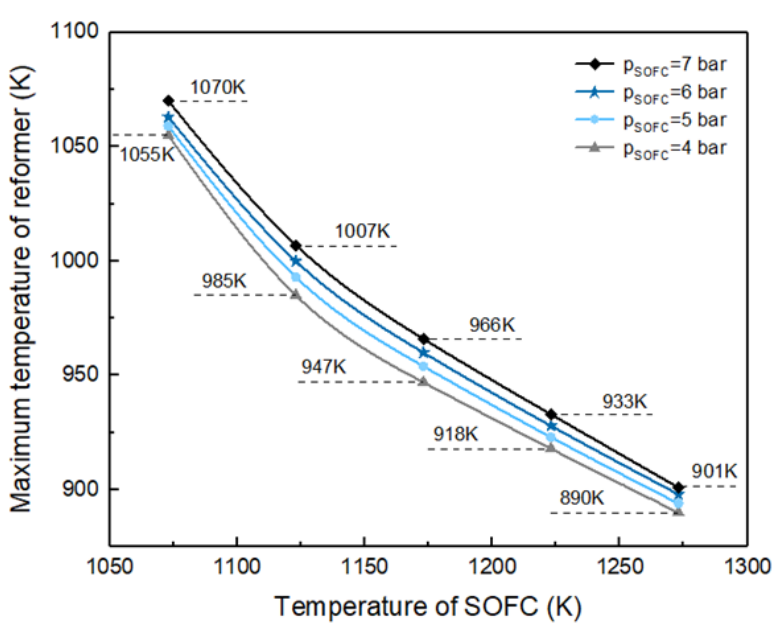

(b) Maximum reformer temperature

Fig. 10. Effects of operating pressures on the reformer $\left(\mathrm{CH}_{4}\right.$-fueled) 


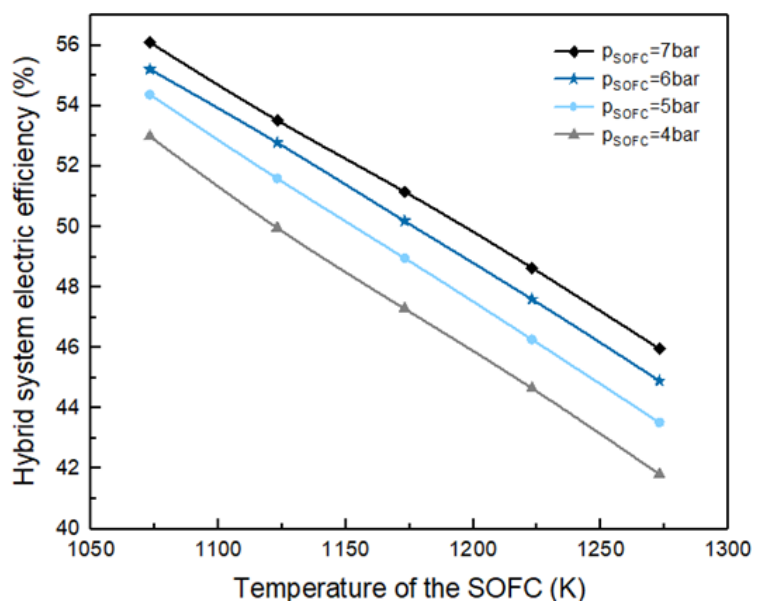

Fig. 11. The electric efficiency of $\mathrm{CH}_{4}$-fueled hybrid system

\section{Carbon monoxide/hydrogen fueled hybrid system}

The CO-fueled system has slightly higher electric efficiency at lower operating pressures when the SOFC temperature keeps the same. However, within the achievable operating range the highest electric efficiency of $54.3 \%$ is obtained at operating pressure of 7 bar due to the extension of allowable SOFC temperature (up to $1205 \mathrm{~K}$ ) caused by this high pressure. Performance boosting technologies, such as blade cooling and anode exhaust cycling are not necessary in this situation, but better arrangements for heat recovery of recuperator hot-side exhausts help to further raise the operational temperature of $\mathrm{SOFC}$. The optimized pressure for $\mathrm{H}_{2}$-fueled system is also 7 bar, where the highest electric efficiency considering the proposed system is achieved $(60.7 \%)$, though this high pressure leads to a decrease in maximum allowable SOFC temperature (1108 K).

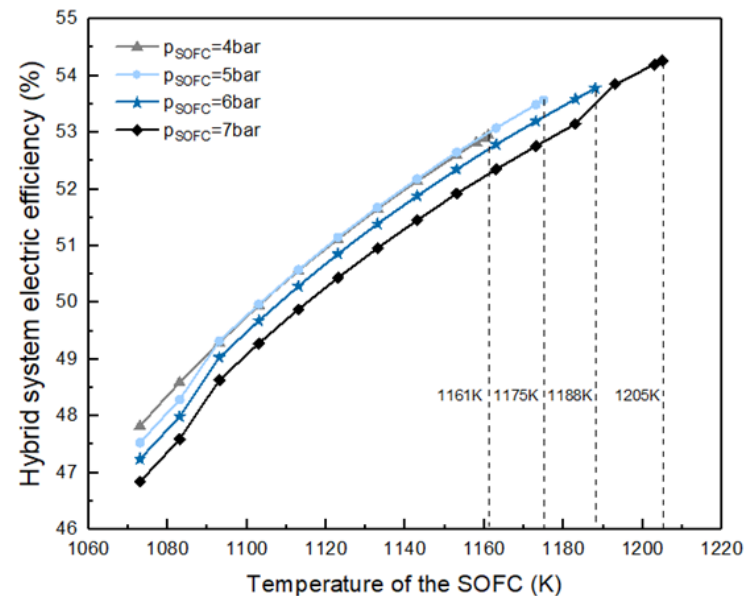

(a) Carbon monoxide fueled

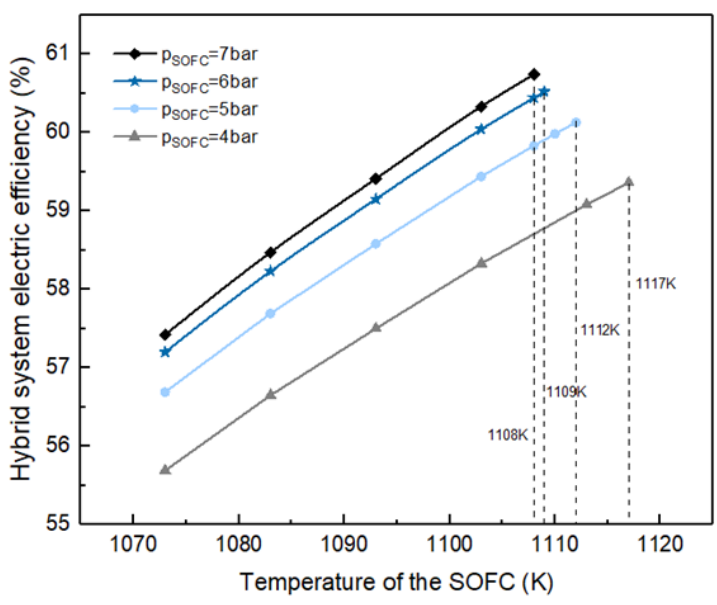

(b) Hydrogen fueled

Fig. 12. Effects of operating pressures on the overall electric efficiency

\subsection{Voltages and electricity output}

Fig. 13 shows how voltages and electricity output of hybrid systems vary within the achievable operating range of SOFC temperature at an optimized operating pressure of 7 bar. The reformer fed with $\mathrm{CH}_{4}$ operates at the corresponding maximum allowable temperature (Fig. 10b), while for $\mathrm{CO}$ 
powered system the reformer operates at the temperature equal to that of pressurized fuel. The SOFC has the widest operating temperature range based on proposed system configuration when $\mathrm{CH}_{4}$ is used as the original fuel but gives lowest operational voltage of $0.62 \mathrm{~V}$ at optimized parameters, compared to $0.75 \mathrm{~V}$ ( $\mathrm{H}_{2}$ fueled) and $0.73 \mathrm{~V}$ (CO fueled) under their respective optimized conditions. It should also be noted that $\mathrm{CH}_{4}$ fueled hybrid system can give the largest amount of total electricity output (1.8 $\mathrm{MW}$ ), around three times the value of $\mathrm{CO}$ or $\mathrm{H}_{2}$ fueled systems, as well as the specific electric work.

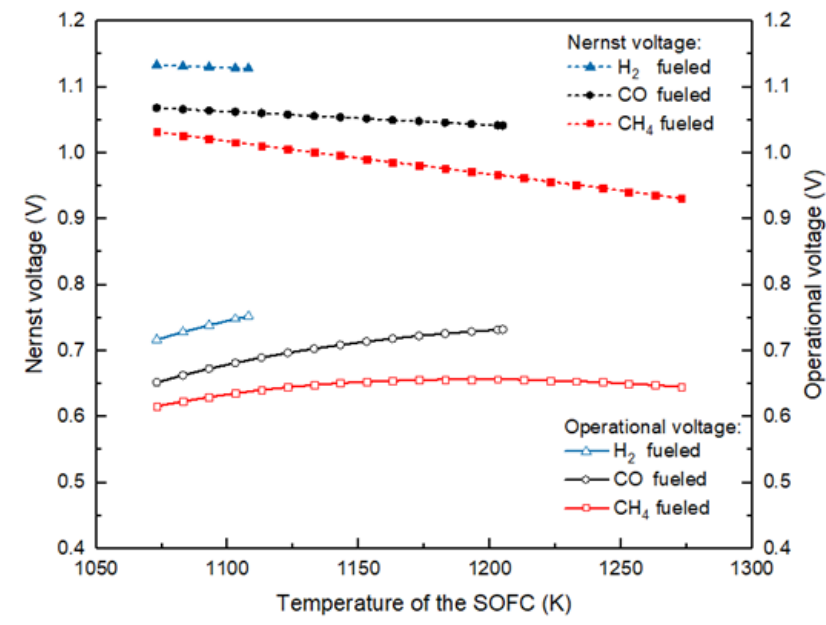

(a) Nernst / operational voltages

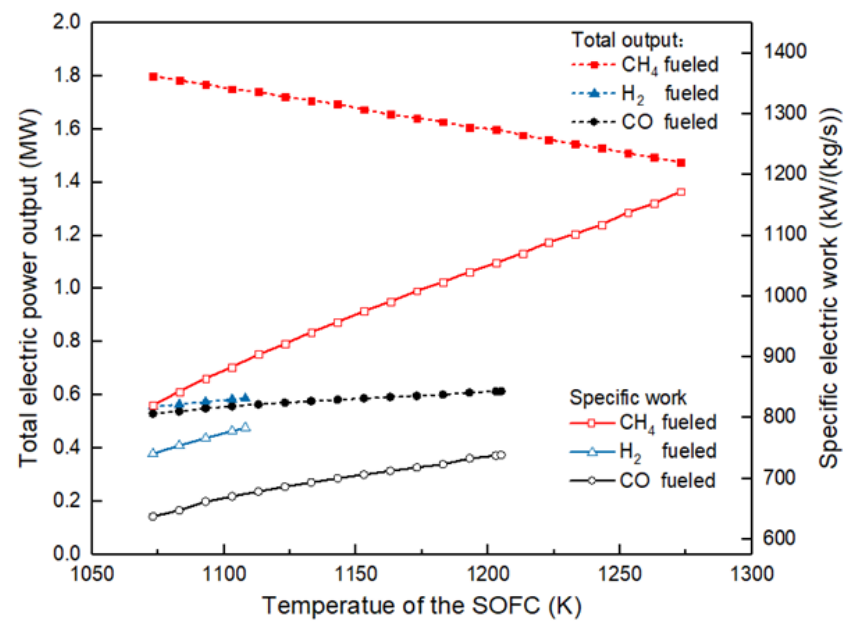

(b) Total / specific electricity output

Fig. 13. Voltages and electricity output of hybrid systems powered by different fuels $\left(p_{S O F C}=7 \mathrm{bar}\right)$

\subsection{Effects of turbines / compressors adiabatic efficiency}

The comparison of electric efficiency of hybrid systems powered with different fuels and the effects of turbines / compressors adiabatic efficiency are shown in Fig. 14. The electric efficiency of $\mathrm{CH}_{4}$ powered system is more dependent on the adiabatic efficiency of turbine. This is because the work generated by the generator occupies a larger proportion of $43 \%$ in the total electricity, compared to $36 \%$ (CO fueled) and $21 \%\left(\mathrm{H}_{2}\right.$ fueled) for a turbine adiabatic efficiency of $85 \%$, as more steam is added to the $\mathrm{CH}_{4}$ powered system and leads to larger total gas amount. Hydrogen powered hybrid system shows the highest overall electric efficiency and sensitivity to compressor adiabatic efficiency.

It is also worth noting that the hybrid system electric efficiency is more sensible to the adiabatic efficiency of turbine. When the adiabatic efficiency of turbine and compressor both increase by $20 \%$, hybrid system electric efficiency rises by $9 \sim 10 \%$ and $5 \sim 7 \%$ respectively. This result is consistent with the study from Zhao et al. [10], and part of the reason for this is that mass flow rate flowing through the turbine is larger than that through the compressor. 


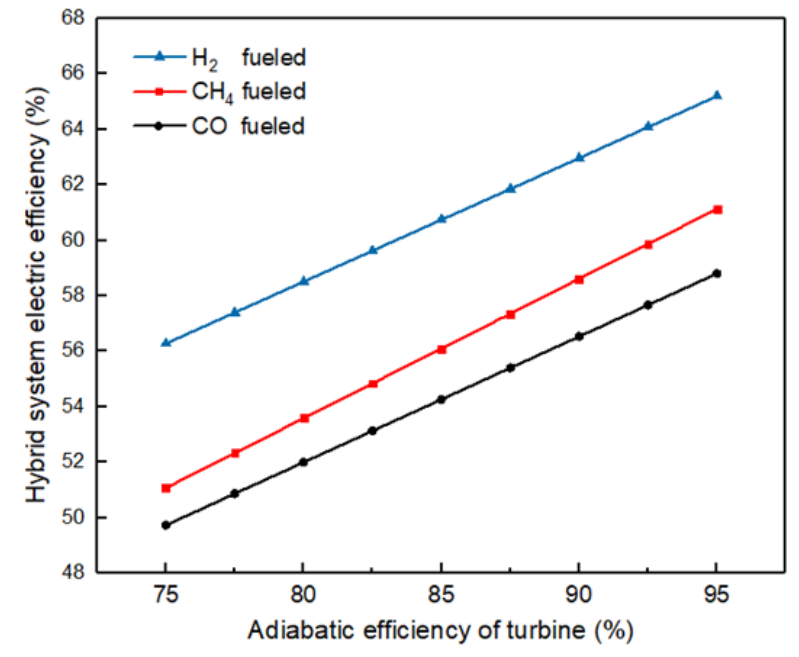

(a) Turbines adiabatic efficiency

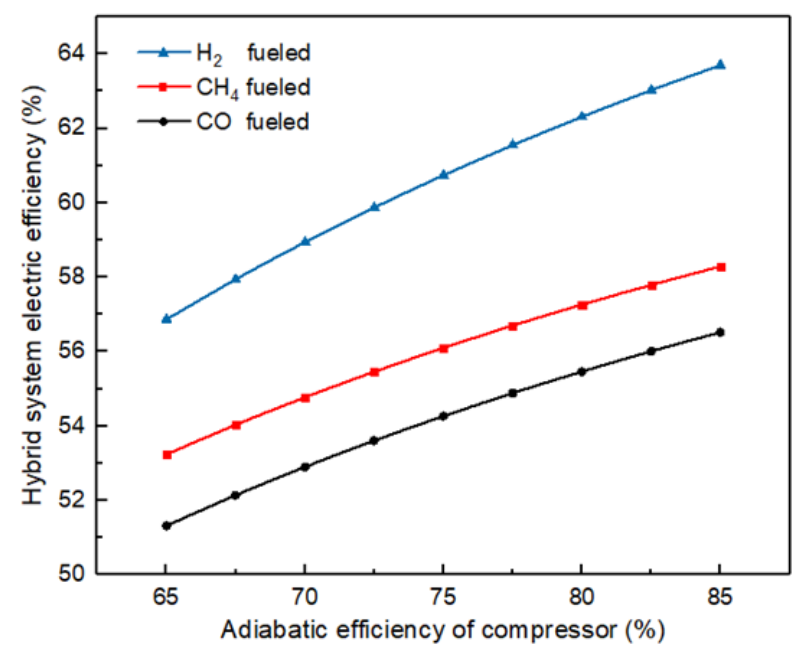

(b) Compressors adiabatic efficiency

Fig. 14. Effects of turbines / compressors adiabatic efficiency

\subsection{Effects of initial fuel composition}

Different performance parameters vary widely in the sensitivity toward initial fuel composition changes, though under certain composition, these parameters show similar pattern of change, which has been discussed above, with varying operating temperatures and pressures of SOFCs and reformers. Hence, the following optimized system performance under different initial fuel composition was obtained at an operating pressure of $7 \mathrm{bar}$, and the SOFC operated at $1073 \mathrm{~K}$ in the $\mathrm{CH}_{4}$ fueled hybrid system. Fig. 15 shows how maximum achievable operating temperature of the reformer $\left(\mathrm{CH}_{4}\right.$ fueled systems) and that of the SOFC ( $\mathrm{CO} / \mathrm{H}_{2}$ fueled systems) changes with initial $\mathrm{CH}_{4} / \mathrm{CO} / \mathrm{H}_{2}$ content.

Table 7 Percentage of decline of performance indicators (\%) with volumetric fraction of $\mathrm{CH}_{4} / \mathrm{CO}$ / $\mathrm{H}_{2}$ decreasing from 0.98 to 0.40

\begin{tabular}{|l|c|c|c|}
\hline Performance indicators & $\mathrm{CH}_{4}$ & $\mathrm{CO}$ & $\mathrm{H}_{2}$ \\
\hline Operational Voltage & 2.90 & 8.27 & 14.2 \\
\hline SOFC electricity output & 65.7 & 61.4 & 64.3 \\
\hline $\begin{array}{l}\text { SOFC-reformer } \\
\text { exergy efficiency }\end{array}$ & 1.33 & 5.91 & 8.35 \\
\hline Total power output & 61.7 & 61.2 & 63.0 \\
\hline Electric efficiency & 7.98 & 6.80 & 11.3 \\
\hline Specific electric work & 1.76 & 22.9 & 27.6 \\
\hline $\begin{array}{l}\text { Power output ratio } \\
\text { (SOFC / total) }\end{array}$ & 10.5 & 0.55 & 3.34 \\
\hline
\end{tabular}

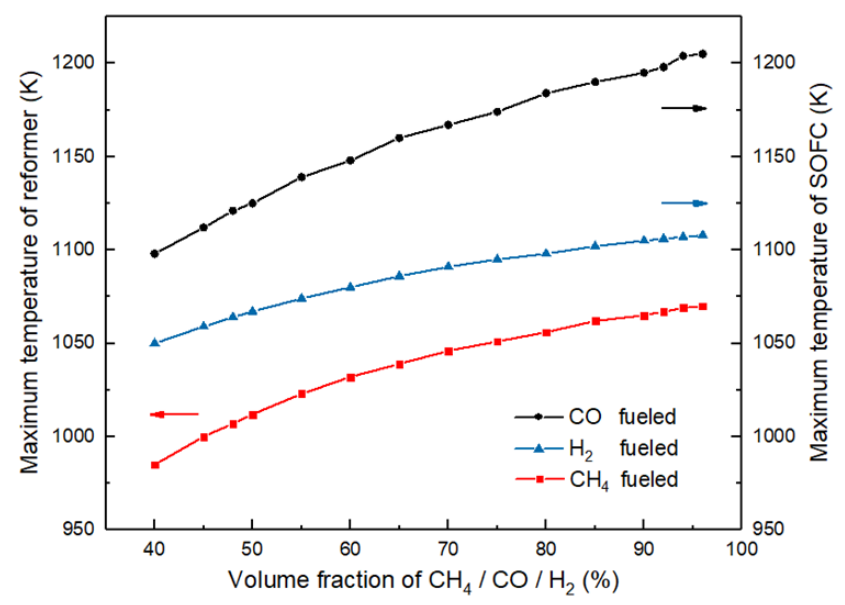

Fig. 15. Effects of $\mathrm{CH}_{4}$ / $\mathrm{CO} / \mathrm{H}_{2}$ volumetric fraction on achievable operating temperature of reformer / $\operatorname{SOFC}\left(p_{S O F C}=7 \mathrm{bar}\right)$ 


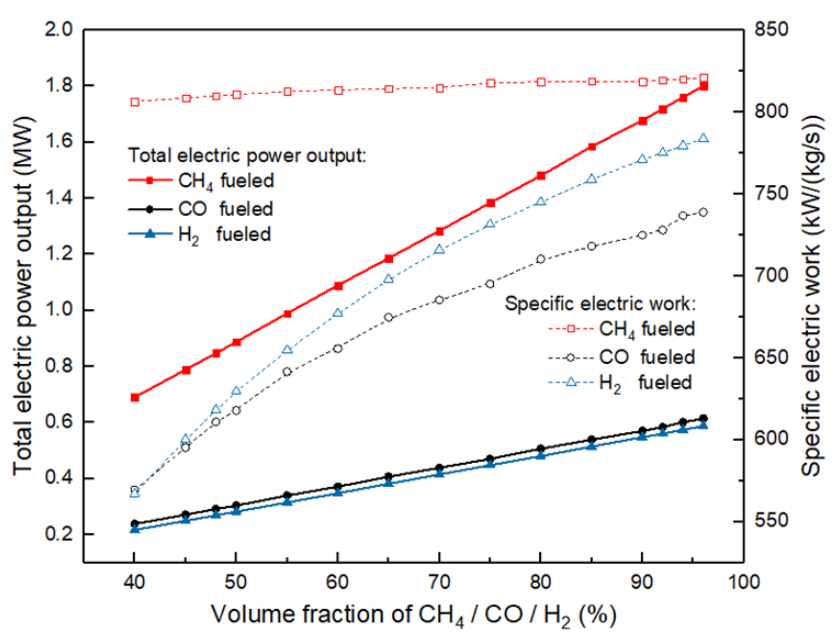

(a) Total and specific electricity output

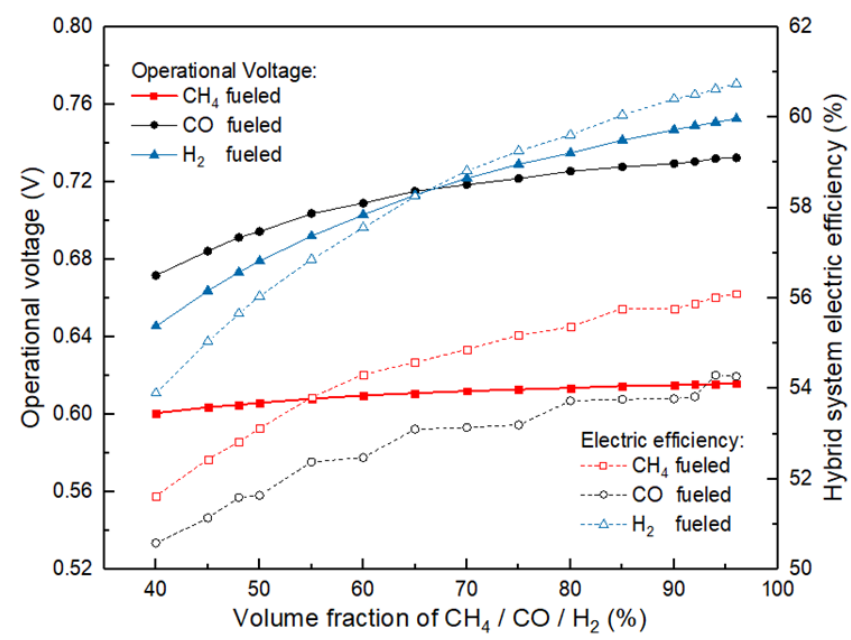

(b) Operational voltage and electric efficiency

Fig. 16. Effects of $\mathrm{CH}_{4} / \mathrm{CO} / \mathrm{H}_{2}$ content on electricity output, voltage and efficiency $\left(p_{S O F C}=7 \mathrm{bar}\right)$

Total electric power output is very sensitive to initial fuel composition, decreasing by over $60 \%$ when the volume fraction of $\mathrm{CH}_{4} / \mathrm{CO} / \mathrm{H}_{2}$ drops from 0.98 to 0.40 (Table 7), though the hybrid system powered by $\mathrm{CH}_{4}$ sees the largest absolute drop in this performance indicator due to its largest base, as shown in Fig. 16a. There is a similar decline (over $60 \%$ ) in electric power generated by the SOFC, and this leads to a change in electricity generation ratio of internal components, namely SOFCs and generators, especially for $\mathrm{CH}_{4}$ fueled hybrid system. However, the system using $\mathrm{CH}_{4}$ as fuel shows very high stability in terms of operational voltage, exergy efficiency of SOFC-reformer integrated system and specific electric work, with these performance parameters decreasing by only $1 \sim 3 \%$ when the volume fraction of $\mathrm{CH}_{4}$ in the initial fuel decreases $58 \%$. This benefits from the two-step conversion reactions of $\mathrm{CH}_{4}$, of which the intermediate product $\mathrm{CO}$, can either be further converted to release $\mathrm{H}_{2}$ (Eq. 2) or be burned in the combustor to generate heat for the downstream gas turbine. Such multi-step reactions and multi-stage utilization provide a buffer when $\mathrm{CH}_{4}$ content in the initial fuel decreases. In contrast, the performance of $\mathrm{H}_{2}$ powered system sees very significant degradation as initial $\mathrm{H}_{2}$ content decreases without similar buffering effects.

\section{Conclusions}

Based on thermodynamic assessment of SOFC - GT hybrid systems powered by $\mathrm{CH}_{4}, \mathrm{CO}$ and $\mathrm{H}_{2}$ respectively, following conclusions are stated:

1. Steam to carbon ratio affects the performance of downstream components and the overall system by changing the volumetric composition of syngas. Carbon monoxide powered system is more sensible to this parameter.

2. Higher operating pressures is favored by hybrid systems powered with different original fuels, though higher pressures give smaller temperature operating range of SOFC in $\mathrm{H}_{2}$ powered system.

3. The allowable operating temperature range of the reformer and SOFC based on the proposed system configuration is very different when $\mathrm{CH}_{4}, \mathrm{CO}$ and $\mathrm{H}_{2}$ are employed as the original fuel respectively.

4. For $\mathrm{CH}_{4}$ fueled hybrid system, there is a corresponding maximum achievable reformer temperature at which the highest electric efficiency at a certain $p_{S O F C}$ and $T_{S O F C}$ can be obtained. The optimized electric efficiency of $56.1 \%$ is achieved with SOFC temperature of $1073 \mathrm{~K}$ and reformer temperature 
of $1070 \mathrm{~K}$.

5. There is a corresponding maximum operating temperature of SOFC for hybrid system powered by $\mathrm{CO}$ or $\mathrm{H}_{2}$ at different compression ratios, based on the proposed system configuration. The optimized electric efficiency of $54.3 \%$ (CO fueled) and $60.7 \%\left(\mathrm{H}_{2}\right.$ fueled) is achieved with SOFC temperature of $1205 \mathrm{~K}$ and $1108 \mathrm{~K}$ respectively $\left(j=0.3 \mathrm{~A} / \mathrm{cm}^{2}, \eta_{t}=0.85, \eta_{c}=0.75, \varepsilon=0.60\right)$.

6. Hydrogen fueled hybrid system gives the highest electric efficiency and operational voltages. Methane powered system gives considerably larger electricity output and specific electric work, though the operational voltage is around $0.1 \mathrm{~V}$ lower than that of $\mathrm{CO}$ or $\mathrm{H}_{2}$ fueled systems.

7. The overall electric efficiency is more sensitive to the turbine adiabatic efficiency, especially for methane powered system, while $\mathrm{H}_{2}$ fueled hybrid system shows higher sensitivity to compressor adiabatic efficiency compared to $\mathrm{CO}$ and $\mathrm{CH}_{4}$ fueled ones.

8. The performance of $\mathrm{H}_{2}$ fueled hybrid system degrades severely with decreasing $\mathrm{H}_{2}$ content in the initial fuel, while the system powered by $\mathrm{CH}_{4}$ shows very high stability in several performance indicators because the multi-stage conversion and utilization of $\mathrm{CH}_{4}$ along the stream flow provide a buffering effect to the decline in initial volume fraction of $\mathrm{CH}_{4}$.

\section{Reference}

[1] International Energy Agency (IEA), “Energy Efficiency Indicators - 2017,” p. 102, 2017.

[2] S. J. McPhail, A. Aarva, H. Devianto, R. Bove, and A. Moreno, "SOFC and MCFC: Commonalities and opportunities for integrated research," Int. J. Hydrogen Energy, vol. 36, no. 16, pp. 10337-10345, 2011.

[3] T. Choudhary and Sanjay, "Thermodynamic assessment of advanced SOFC-blade cooled gas turbine hybrid cycle,” Int. J. Hydrogen Energy, vol. 42, no. 15, pp. 10248-10263, 2017.

[4] A. Buonomano, F. Calise, M. D. d'Accadia, A. Palombo, and M. Vicidomini, "Hybrid solid oxide fuel cells-gas turbine systems for combined heat and power: A review," Appl. Energy, vol. 156, pp. 32-85, 2015.

[5] J. D. Wilson, C. M. Colson, and M. H. Nehrir, "Cost and unit-sizing analysis of a hybrid SOFC/microturbine generation system for residential applications," in North American Power Symposium 2010, 2010, pp. 1-6.

[6] L. Duan, K. Huang, X. Zhang, and Y. Yang, "Comparison study on different SOFC hybrid systems with zero-CO2 emission,” Energy, vol. 58, pp. 66-77, 2013.

[7] M. L. Ferrari, U. M. Damo, A. Turan, D. Sanchez, Hybrid systems based on solid oxide fuel cells : modelling and design, First edition. Chichester, UK ; Wiley, 2017.

[8] J. Pirkandi, M. Mahmoodi, and M. Ommian, "Thermo-economic performance analysis of a gas turbine generator equipped with a pressurized and an atmospheric solid oxide fuel cell," Energy Convers. Manag., vol. 136, pp. 249-261, 2017.

[9] J. Pirkandi, M. Mahmoodi, and M. Ommian, "An optimal configuration for a solid oxide fuel cell-gas turbine (SOFC-GT) hybrid system based on thermo-economic modelling," J. Clean. Prod., vol. 144, pp. 375-386, 2017.

[10] Y. Zhao, J. Sadhukhan, A. Lanzini, N. Brandon, and N. Shah, "Optimal integration strategies for a syngas fuelled SOFC and gas turbine hybrid," J. Power Sources, vol. 196, no. 22, pp. 
9516-9527, 2011.

[11] E. Facchinetti, M. Gassner, M. D’Amelio, F. Marechal, and D. Favrat, "Process integration and optimization of a solid oxide fuel cell - Gas turbine hybrid cycle fueled with hydrothermally gasified waste biomass," Energy, vol. 41, no. 1, pp. 408-419, 2012.

[12] B. Tarroja, F. Mueller, J. Maclay, and J. Brouwer, "Parametric Thermodynamic Analysis of a Solid Oxide Fuel Cell Gas Turbine System Design Space," J. Eng. Gas Turbines Power, vol. 132, no. 7, p. 072301, 2010.

[13] Y. Yi, A. D. Rao, J. Brouwer, and G. S. Samuelsen, "Fuel flexibility study of an integrated 25 kW SOFC reformer system," J. Power Sources, vol. 144, no. 1, pp. 67-76, 2005.

[14] Y. Li and Y. Weng, "Performance study of a solid oxide fuel cell and gas turbine hybrid system designed for methane operating with non-designed fuels," J. Power Sources, vol. 196, no. 8, pp. 3824-3835, 2011.

[15] T. Krummrein, M. Henke, P. Kutne, and M. Aigner, "Numerical analysis of operating range and SOFC-off-gas combustor requirements of a biogas powered SOFC-MGT hybrid power plant," Appl. Energy, vol. 232, no. October, pp. 598-606, 2018.

[16] N. F. Harun, D. Tucker, and T. A. Adams, "Impact of fuel composition transients on SOFC performance in gas turbine hybrid systems," Appl. Energy, vol. 164, pp. 446-461, 2016.

[17] EG\&G Technical Services, Inc. (2004) Fuel cell handbook (7th edn) EG\&G Technical Services, Inc. Morgantown, WV.

[18] H. Uechi, S. Kimijima, and N. Kasagi, "Cycle Analysis of Gas Turbine-Fuel Cell Cycle Hybrid Micro Generation System,” J. Eng. Gas Turbines Power, vol. 126, no. 4, p. 755, 2004.

[19] S. H. Chan, H. K. Ho, and Y. Tian, "Modelling of simple hybrid solid oxide fuel cell and gas turbine power plant," J. Power Sources, vol. 109, no. 1, pp. 111-120, 2002.

[20] K. Tanaka, C. Wen, and K. Yamada, "Design and evaluation of combined cycle system with solid oxide fuel cell and gas turbine," Fuel, vol. 79, no. 12, pp. 1493-1507, 2000.

[21] S. A. Hajimolana and M. Soroush, "Dynamics and control of a tubular solid-oxide fuel cell," Ind. Eng. Chem. Res., vol. 48, no. 13, pp. 6112-6125, 2009.

[22] S. F. Sghaier, T. Khir, and A. Ben Brahim, "Energetic and exergetic parametric study of a SOFC-GT hybrid power plant," Int. J. Hydrogen Energy, vol. 43, no. 6, pp. 3542-3554, 2018.

[23] C.-W. Nien, "Design and development of combined fuel cell-gas turbine cycles for environmentally friendly, efficient power generation." University of Manchester, Manchester, 2007. 